\title{
Migration, Risk and Liquidity Constraints in El Salvador
}

\author{
Timothy Halliday* \\ University of Hawai'i at Mānoa
}

Department of Economics and John A. Burns School of Medicine

Fourth Draft:

March 28, 2006

\begin{abstract}
This paper utilizes panel data from El Salvador to investigate the use of trans-national migration as an ex post risk management strategy. We show that adverse agricultural conditions in El Salvador increase both migration to the US and remittances sent back to El Salvador. We show that, in the absence of any agricultural shocks, the probability that a household sent members to the US would have decreased by $24.26 \%$, on average. We also show that the 2001 earthquakes reduced net migration to the US. A one standard deviation increase in earthquake damage reduced the average probability of northward migration by 37.11\%. The evidence suggests that the effects of the earthquakes had more to do with
\end{abstract}

*I thank Claudio Gonzalez-Vega of the Department of Agricultural Economics at the Ohio State University for permission to use their data. I also thank Alvaro Trigueros of La Universidad Centroamericana in San Salvador for sharing his breadth of knowledge of El Salvador. Finally, I am grateful to the editor and two anonynous referees for useful comments. All errors are my own. Address: University of Hawai'i at Mānoa; Department of Economics, 533 Saunders Hall, Honolulu, HI 96822. Phone: (808) 956 - 8615. 
households retaining labor at home to cope with the effects of the disaster rather than the earthquakes disrupting migration financing.

JEL Classification: O1

Key Words: Migration, Insurance, Liquidity Constraints

\section{Introduction}

There is a vast literature in development economics that has investigated how households in LDC's cope with exogenous economic shocks in the face of imperfect insurance markets. ${ }^{1}$ This literature consists of two strands. In the first, researchers have looked at informal means of allocating risk across space in which households within a group such as a village insure each other via state-contingent transfers. ${ }^{2}$ In the second strand, researchers have looked at the household's use of asset accumulation and depletion, in autarky, as a means of self-insurance. ${ }^{3}$ This paper

\footnotetext{
${ }^{1}$ For a more thorough overview of the literature on savings, credit and insurance arrangements in developing countries, we refer the reader to Besley (1995).

${ }^{2}$ For example, Udry (1994a) looks at the role that state-contingent credit contracts play in risk management for households in northern Nigeria. He finds that repayment depends not only on shocks to the borrower but also to the lender. This result is not consistent with a standard model of loan contracting; rather, it has more in common with a model of cross-sectional risk pooling. In a related work, Townsend (1994) uses the ICRISAT data set to look at villages in India and concludes that idiosyncratic risk matters relatively little for household consumption once he controls for village level risk. Despite finding evidence of cross-sectional risk sharing, both papers reject the null of efficient risk sharing, although Townsend concludes that the complete markets paradigm fairs reasonably well in the ICRISAT data. However, Chaudhuri and Raviollion (1997) provide a comment to Townsend's work. Their work indicates that a particular form of measurement error in Townsend's consumption data may have been a potentially important factor that biased some of Townsend's results towards the null of efficient risk sharing. Their work lends credence to Deaton (1992) who claims that the co-movements in consumption that are observed in the ICRISAT data may be rationalized by an autarkic model of savings in which different households receive common signals concerning future income.

${ }^{3}$ In one example, Udry (1994b) looks at a sample of rural dwellers from northern Nigeria and finds that grain inventories grow more slowly upon the receipt of adverse shocks. In a similar piece, Paxson (1992) tests the
} 
adds to this part of the literature by treating the number of migrants within a household as a productive asset and investigating how and why various exogenous economic shocks affect its movement.

There has been substantial work on the use of migration as a means of mitigating risk prior to the occurrence of a shock, or as an ex ante risk management strategy (Rosenzweig and Stark 1989; Paulson 2000). However, there has been surprisingly little work done on the use of migration as a means of mitigating risk after the occurrence of a shock, or as an ex post risk management strategy. Helping to fill this void is this paper's main objective.

To accomplish this, we use a panel of rural households from El Salvador. The data that we employ in this paper cover the years 1997, 1999 and 2001. They contain information on the number of migrants per household. Because we have a panel, we are able to measure the household's migrant flow through the difference in migrant stocks across two time periods. Since our data come from El Salvador and not the US, we are better able to account for illegal as well as legal migration. In addition, we have good data on exogenous events that affect the household in El Salvador. These events come from two sources. The first is agricultural conditions which caused livestock loss and/or harvest loss during the years 1999 and 2001. The second is damage sustained by the household due to the 2001 earthquakes. Because the final survey was fielded in the beginning of 2002 and the earthquakes occurred in the beginning of 2001, it provides good measurement of the earthquake's effects.

El Salvador provides us with an excellent laboratory for this work due to the high volume

Permanent Income Hypothesis with a sample of rural farmers in Thailand using rainfall data. She finds that farm households save a significantly larger portion of transitory income than permanent income, thereby suggesting that savings is used to smooth consumption from transitory income fluctuations. In another study, Rosenzweig and Wolpin (1993) show that farmers in India are more apt to sell bullocks when they experience low profits. 
of migration in the country. While Salvadoran migration to the US was somewhat common prior to 1980, it gained momentum in the eighties primarily due to a civil war which was fought during that decade. Upon the signing of the peace accords in 1992 by the government and the FMLN, the umbrella group for the opposition during the war, now a political party, many expected that these migrant flows would abate. However, this has proven not to be the case. Indeed, according to the 2000 US Census, the number of Salvadorans in the US is estimated to be 784,700. In contrast, the 1990 census estimate is 418,800 (Ruggles, Sobek, et al. 2003).,5

Our results indicate that these large migrant flows are, in part, affected by the economic conditions which prevail in El Salvador. We find that adverse agricultural shocks such as harvest and livestock loss have large and positive effects on the household's probability of sending members to the US. In particular, in the absence of any agricultural shocks, on average, the probability that a household sent members to the US would have dropped by $24.26 \%$. We also find that households that experience adverse agricultural conditions also experience increases in remittances that are on the order of $40 \%$ to $60 \%$.

In contrast, our results indicate that the dollar amount of damage due to the earthquakes is associated with a substantial decrease in net migration to the US. A one standard deviation increase in damage lowers the probability of migration to the US by $37.11 \%$. One explanation for this finding is that the earthquakes created exigencies in El Salvador which increased the incentives for families to retain labor at home. This explanation states that the labor of potential

\footnotetext{
${ }^{4}$ Of course, due to the difficulty of counting undocumented workers, it is likely that this number provides us with a lower bound of the actual number of Salvadorans residing in the US. Indeed, many estimate that the actual number is now well above one million (PNUD 2001). In a country of just over six million people, this has astounding implications for the number of Salvadorans residing abroad.

${ }^{5}$ In addition, the high prevalence of Salvadorans in the US has had significant implications for the volume of money remitted to El Salvador from the US each year. In fact, the Salvadoran government estimates that remittances contributed 1.75 billion dollars to the Salvadoran GNP in 2000 (PNUD 2001; MRE 2001). This amount accounted for $13 \%$ of the Salvadoran GNP in 2000.
} 
and existing migrants was used to buffer the effects of the earthquakes. Another explanation for this result is that Salvadoran households are liquidity constrained and that the earthquakes disrupted migration financing either through depleting savings or restricting access to credit.

To investigate the role that liquidity constraints play, we look into the relationship between household wealth, migration and the earthquakes. The basic idea behind this exercise is that wealthier households are less likely to be credit constrained and, hence, better able to finance migration As expected if households are liquidity constrained, we find that higher levels of wealth are associated with a higher probability of migration. However, we also find that the earthquakes stunted migration to the US at all wealth levels. Thus, the earthquakes appear to have had as much of an effect on wealthier households, who are less likely to be liquidity constrained, as they had on poorer households, who are more likely to be liquidity constrained. Accordingly, the evidence in this paper does not support the hypotheses that the earthquakes stunted migration as a consequence of the disruption of migration financing.

The remainder of this paper is organized as follows. In Section 2, we describe the data. Section 3 looks into the impact of exogenous shocks on migration and remittances. Section 4 explores alternative explanations for the results of Section 3. In Section 5, we extend the analysis of Section 3 and look into the role that liquidity constraints play. Section 6 concludes.

\section{The Data}


The data that we employ come from the BASIS research program in El Salvador at The Ohio State University. The data set is a panel of rural households in El Salvador. ${ }^{6}$ We employ data on migration, remittances, demographic characteristics and wealth from the 1997, 1999 and 2001 waves of the survey as well as data on exogenous shocks from the 1999 and 2001 waves. The data contain household identifiers, so it is possible to track households across time. Variable definitions and summary statistics are provided in Table 1 . Table 2 reports sample sizes by year.

\subsection{Migration}

The primary migration variables that we work with are Migrants and Remittances. Precisely, we define a migrant to be anyone in the household who, at the time of the survey year, was residing in the US or Canada. ${ }^{7}$ The average number of migrants per household in our data is 0.55. $26.44 \%$ of all households report having at least one migrant. Among the households who report having migrants, the average number of migrants per household is 2.08 . Remittances is a measure of the total amount of money sent back from the US to the household in El Salvador in a given time period. The average remittance level per household is $\$ 303.29$. However, conditional on having at least one migrant residing in the US, the average remittance level rises to $\$ 1110.98$.

\footnotetext{
${ }^{6} \mathrm{El} \mathrm{Salvador}$ is divided into 14 departments which, in turn, are divided into municipios which are further subdivided into cantones. Households are defined to be rural if they live in a cantón that is not the capital of their municipio. Several cantones within the municipio of San Salvador were not classified as rural due to the expansion of the capital city.

${ }^{7} \mathrm{~A}$ person is defined to be a household member if they are either tied to the household by blood by or by marriage.
} 


\subsection{Shocks}

Our shocks come from two sources. The first source is household specific agricultural conditions which prevailed during the years 1999 and 2001. The second source is the earthquakes of 2001.

\subsubsection{Agricultural Shocks}

Our measures of household-specific agricultural shocks come from two events: livestock loss and harvest loss. In the 2001 and 1999 panels of the data, the enumerators solicited information concerning whether or not the household experienced income loss due to either event. If the household indicated that they did lose income as a consequence of any of these events then Harvest Loss or Livestock Loss equals one; otherwise, it equals zero. Similar self-reported shocks have been used by Udry (1994a and 1994b) in his work on risk management in Nigeria. ${ }^{8}$

We report the distribution of our agricultural shocks in Table 3. For both the 2001 data and the 1999 data, $25.99 \%$ of all households experienced at least one agricultural shock. The prevalence of shocks was substantially higher in the 2001 panel. The percentage of households experiencing shocks rose from $16.67 \%$ in 1999 to $35.41 \%$ in 2001 . One possible reason for this dramatic increase was the drought of $2001 .^{9}$ Finally, the majority of households who experienced agricultural shocks did so due to harvest loss; however, a non-trivial number of households, 149 or $10.76 \%$ of all households present in 1999 and 2001, also experienced livestock losses.

\footnotetext{
${ }^{8}$ Because the survey design differed slightly across 1999 and 2001, the construction of the harvest loss variable warrants some more exposition. In 1999, the household was defined to have experienced a harvest loss if they reported that they lost all or part of their harvest and that this event caused them to lose income. In 2001, the household was defined to have experienced a harvest loss if they reported that the value of their harvest was less than normal as a consequence of a drought which occurred in 2001. Unfortunately, the 1999 survey did not solicit the actual cause of the harvest loss and, hence, it is not possible to have comparable measures of harvest losses in 1999 and 2001. To address this issue, we estimated our models separately for 1999 and 2001 to ensure that the results were comparable in the two years and they were.

${ }^{9}$ In El Salvador, the rainy season occurs between May and October. During the months of June and July, there is a dry period called the "canicula." Droughts typically occur when the canicula is longer than normal.
} 


\subsubsection{Earthquake Shocks}

The earthquakes of 2001 provide us with a second shock. The earthquakes occurred on January 13 and February 13 of 2001. The first earthquake registered 7.6 on the Richter scale and killed a total of 844 people. The second earthquake registered 6.6 on the Richter scale and killed an additional 315 people. Out of El Salvador's approximate six million people, it is estimated that over one million people were left without adequate shelter by the middle of February 2001 (Nicolás and Olson 2001).

Earthquake Damage, our second shock, is an index that measures the extent to which the dwelling of a household was affected by the 2001 earthquakes. It is equal to the log of the total cost of the damage sustained. Damage came from numerous sources. Table 4 describes in detail all the sources of damage from the earthquakes that are used to construct the index. As can be seen in the table, home damage was the principal source of damage. In our data, the dwellings of $59.6 \%$ of households were affected in some way by the earthquakes. $31.6 \%$ of households reported that they sustained at least major damage to their homes. $17 \%$ of households reported having their homes destroyed or rendered uninhabitable. This number coincides with the estimate that approximately 1 out of 6 Salvadorans was left without adequate housing in the wake of the disaster, thereby, suggesting that our measure of the earthquake shock is good. ${ }^{10}$ Finally, the average cost of damage among households who actually sustained damage was $\$ 5202.12$. Figure 1 displays the density of Earthquake Damage for each of El Salvador's 14 departments.

\footnotetext{
${ }^{10}$ It is not possible that the statistics from this study were constructed with the BASIS data since the study was released in mid-2001 and the BASIS survey was fielded in 2002.
} 


\subsection{Demographic Characteristics}

We also use demographic controls. To control for household composition, we construct measures of the number of household members residing at home in El Salvador within certain age and gender brackets for all home dwellers. We only focus on the demographic composition of the household at home in El Salvador in the coming analysis since we are primarily interested in controlling for the effects of young children and elderly household members on migration decisions. $^{11}$ Table 5 reports the descriptive statistics for our household demographic variables. We report the mean and standard deviations for the number of household members within each age/gender bracket. ${ }^{12}$ Finally, we employ data on the education of the household head. These descriptive statistics are reported in Table 1.

\subsection{Wealth}

We employ data on the household's total land holdings, which are measured in manzanas as a proxy for wealth. ${ }^{13,14}$ We use three measures which are defined in Table 1 . The first measure, Land 1, includes all the holdings of the household for which there is either a title or documents

\footnotetext{
${ }^{11}$ The age brackets that we employ are: less than age 6 , between ages 6 and 10, between ages 11 and 15 , between ages 16 and 20, between ages 21 and 40, between ages 41 and 60 and older than age 60 .

${ }^{12}$ Interestingly, there are no significant differences in the gender composition of the household for household members less than or equal to 20 years of age. However, we do observe significant differences in household composition across gender for household members older than 20 years. In particular, we observe that there are significantly less male household members residing in El Salvador between the ages of 21 and 60 . The reason for this is that there is a relative abundance of men between these ages residing in the US. What is not clear, however, is why there are significantly more men over the age of 60 . Presumably, this reflects a weakness in our data.

${ }^{13}$ One manzana equals 6988 square meters.

${ }^{14} \mathrm{An}$ alternative proxy for wealth in the BASIS data is savings. However, only about $20 \%$ of households have positive savings in our data in the years 1999 and 2001, whereas, roughly $50 \%$ to $60 \%$ of households have positive land holdings in these years depending on which measure we use. Consequently, we felt that land holdings was a more comprehensive proxy of wealth for our sample.
} 
indicating the power of transfer. ${ }^{15}$ The second measure, Land 2, is Land 1 plus any land that the household may be using with no proper legal documentation. ${ }^{16}$ The third measure, Land 3, is the least inclusive. It only includes land that has a title. Our preferred measure is Land 1 as it is comprehensive, but not so comprehensive that it includes land that households would have difficulty selling. However, we also use the other measures as a robustness check.

\subsection{Attrition in the BASIS Panel}

An important issue to consider when working with panel data is attrition, particularly, whether or not it occurs randomly. Table 2 provided some insights into attrition in the BASIS data. The table showed that roughly $92 \%$ of the original households in 1997 survived until 2001 so that attrition was about 8\% over a four year period. Between 1999 and 2001, attrition was less than $4 \% .{ }^{17,18}$

\footnotetext{
${ }^{15}$ Specifically, the survey asks the household whether or not they have a "título" or an "acta de transferencia de dominio." The latter does not have the same legal guarantees as a title, but can used as a means of obtaining a title. However, due to reasons associated with poverty and lack of education many people with the acta de transferencia do not take the necessary steps to obtain a title. I thank Alvaro Trigueros of FUSADES for clarifying this point. $2.8 \%$ of households in our data had land with an acta de transferencia but no title. $49.7 \%$ of households in the data had land with a title.

${ }^{16} 11.6 \%$ of the households in our data had land with no proper documentation.

${ }^{17}$ Unfortunately, we do not know whether households left the survey because they migrated, died or refused to respond. However, according to economists at FUSADES, a policy-oriented think-tank in El Salvador which shared responsibilities for administering the survey along with the Ohio State University, there is a common belief that migration was the primary cause of attrition. This accords well with Thomas, Frankenberg and Smith (2001) who provide direct evidence that migration was the primary cause of attrition in the Indonesian Family Life Survey (IFLS).

${ }^{18} \mathrm{It}$ is informative to compare attrition in the BASIS data with that of other more commonly used panels. In the IFLS, for example, there were three waves in 1993, 1997 and 1998. Between 1993 and 1997, attrition was 6\%. Interestingly, between 1993 and 1998, attrition was actually lower at 5\%. This low rate of attrition is quite remarkable given that attrition in panels from developing countries is notoriously high. It is also remarkable given that attrition in some commonly used American panels is substantially higher. For example, in the Panel Study of Income Dynamics, attrition was about 12\% between 1968 and 1969 - a one year time period. In a more current survey, the Health and Retirement Survey, attrition was about 9\% between 1991 and 1993. Thomas, Frankenberg and Smith (2001) credit a conscientious effort at tracking movers for the low rate of attrition in the IFLS. Indeed, it is reassuring that attrition in the BASIS data is lower than many panels from the developing world and even some from the developed world, although it is substantially higher than the IFLS.
} 
A useful exercise when thinking about the potential impact that attrition may have on estimation is to regress variables indicating survival in the panel on baseline household characteristics. This is a common exercise in the literature on panel attrition. For more information, we refer the reader to Gottschalk, Fitzgerald and Moffit (1998) and Thomas, Frankenberg and Smith (2001). We report the results in Table $6 \cdot^{19,20}$

We are careful to include variables indicating how prone the household is to shocks. In the first, second and third columns, we included the percentage of households in a municipio in 1999 and 2001 that experienced harvest and livestock loss. ${ }^{21}$ In column three, we simply included the harvest loss and livestock loss variables from 1999. Also, we included the mean of earthquake damage within municipios in all four columns. The logic behind this is that if proneness to shocks is correlated with survival then this could generate potentially serious biases in the estimation of the impact of shocks on migration, particularly since the attrition literature has shown that panel survival is negatively correlated with migration. ${ }^{22}$

The results do not reveal many significant predictors of attrition. Land holdings is by far the most important with more landed households more likely to survive. This is not surprising given that households with more land are, presumably, less mobile and, hence, easier to track across survey years. In terms of the coming estimation, this is not of tremendous concern as any

\footnotetext{
${ }^{19}$ Right-hand side variables include baseline characteristics such as land holdings, a dummy indicating positive land holdings, number of migrants, the head's education, a dummy indicating that the household size is one, household size, the demographic variables described in Section 2.3 and department dummies.

${ }^{20}$ The first two columns estimate the probability of surviving from 1997 to 2001 . The third column estimates the probability of surviving from 1999 to 2001 and the fourth column estimates the probability of surviving from 1997 to 1999. In the first, second and fourth columns, baseline characteristics are from the 1997 survey. In the third column, which looks into survival from 1999 to 2001, the baseline characteristics come from the 1999 survey.

${ }^{21} \mathrm{El}$ Salvador is divided into 14 departments which are further divided into municipios

${ }^{22}$ Ideally, if we had shocks from all of the baselines, we would have looked at whether or not households that received shocks were also more likely to leave the panel. This type of exercise was only possible using 1999 as the baseline with the agricultural shocks, but it was not possible with 1997 as the baseline since the survey did not solicit information on shocks in that year. Consequently, we used municipio-level aggregates.
} 
potential bias that this might cause can be mitigated by controlling for land holdings. Turning to the shock variables, we see that the tests of joint-significance on the agricultural shocks are all soundly rejected both with and without the department dummies. There is some evidence, however, in the first and last columns that proneness to earthquake damage is weakly correlated with survival. This is potentially problematic and we address this issue in Section 4 .

\section{Migration, Remittances and Risk}

\subsection{The Impact of Shocks on Migration}

We begin by estimating the response of the household's migration decision to shocks in El Salvador. Let $M_{h, t}$ denote the migrant stock of household $h$ at time $t$. Let $\Delta M_{h, t}$ denote the change in the household's migrant stock across survey years. Let $\omega_{h, t}$ denote a vector of exogenous events that affect the household at time $t$ which includes Harvest Loss, Livestock Loss and Earthquake Damage. Next, we let $Z_{h, t}$ denote a vector of household demographic variables which were described in Section 2.3. ${ }^{23}$ Finally, we let $X_{h, t}$ denote other control variables such as location dummies and time dummies. This notation is held throughout the balance of the paper.

\footnotetext{
${ }^{23}$ In this section we do not address the effects of household wealth on migration. The reason for this is that wealth has a positive effect on both northward migration (i.e. $\Delta M_{h, t}>0$ ) and southward migration (i.e. $\left.\Delta M_{h, t}<0\right)$ in our data and the parsimonious econometric model that we work with in this section does not allow for such non-monotonicity. We reserve a discussion of the effects of wealth on migration for Section 5 when we address the role that liquidity constraints play in migration decisions.
} 
To assess the impact of shocks on migration, we estimate the ordered response model

$$
\begin{gathered}
1\left(\Delta M_{h, t}=n\right)=1\left(\alpha_{n-1} \leq \delta_{1} \omega_{h, t}+\delta_{2} X_{h, t}+\delta_{3} Z_{h, t-1}+\varepsilon_{h, t}<\alpha_{n}\right) \\
\text { for } n \in\{\ldots,-1,0,1, \ldots\} .
\end{gathered}
$$

$\alpha_{n}$ denotes the $n$th ancillary parameter. We assume that $\varepsilon_{h, t}$ is independent of the vector $\left(\omega_{h, t}, X_{h, t}, Z_{h, t-1}\right)$ and follows a logistic distribution. The advantage of the ordered response model in equation (1) is that the additional ancillary parameters allow us to handle $\Delta M_{h, t}$ in a flexible manner. We are careful to include lags of the household's demographic characteristics. We do this since migration decisions today will affect the household's demographic composition in the present period.

Table 7 presents the results. ${ }^{24,25}$ In all five columns, we see that adverse agricultural conditions in El Salvador had a positive effect on migration and, thus, tended to push people out of the country. The variables, Livestock Loss and Harvest Loss, are all positive and individually significant at the $10 \%$ level and they are jointly significant at the $5 \%$ level. ${ }^{26}$ These results are

\footnotetext{
${ }^{24}$ The standard errors in this table (and all of the tables in the coming analysis) allow for clustering within municipios. We do so for two reasons. The first is that we often work with the same household observed across multiple time periods. The second is that we expect many of our variables, particularly the shocks, to be spatially correlated. Accordingly, standard errors that assume that the data are distributed i.i.d. will be incorrect. For a more thorough discussion of clustering, we refer the reader to Deaton (1997). However, it is important to state that while the asymptotic justification for this procedure is clear in linear models, this justification is less clear in non-linear models as it would seem that correlated unobservables would fundamentally alter the likelihood function. Nevertheless, we admonish the reader to view this clustering procedure as a "down and dirty" solution to the problem of spatial correlation.

${ }^{25}$ We also have a version of the results in this table using the Inverse Probability Weighting (IPW) Scheme developed by Moffitt, Fitzgerald and Gottschalk (1999). This procedure corrects for a particular form of attrition bias which occurs when the attrition is affected by observable characteristics in the first time period, but is unaffected by outcomes which occur in subsequent time periods. The results are very similar and are available upon request. Despite this, however, it is important not to place too much stock in the IPW results as attrition in our case is often being caused by migration and this type of attrition cannot be accommodated by IPW.

${ }^{26}$ We also estimated these models individually using only single years of the panel. While, not surprisingly, the estimates are less precise, they still paint the same picture as Table 7 . What is interesting about this exercise is that we know that the primary cause of agricultural shocks in 2001 was a draught. Moreover, we know for
} 
consistent with Munshi (2003) who shows that low rainfall in Mexico has a positive impact on migration to the US.

The relationship between agricultural shocks and migration suggests that households who experienced agricultural losses anticipated low expected returns to their labor at home for the foreseeable future and, thus, a widened north-south wage gap. Consequently, the shocks may have created additional incentives to send household members to the US and disincentives for existing migrants to return to El Salvador. In addition, as we will see, there is some evidence that the effects of the agricultural shocks on migration are accompanied by rises in remittances.

In contrast, the table shows that the earthquakes had a negative impact on migration. The earthquake damage index is negative and significant in columns 1 and 3 . In column 2, we include a dummy variable indicating whether or not the household was affected by the disaster, in lieu, of the index. The dummy variable, which tells us the average impact of the earthquakes, is negative and moderately significant. In columns 4 and 5, we include 14 department dummies and 167 municipio dummies, respectively, and we see that the standard error on Earthquake Damage is larger, but the point estimate is similar to what it was in column $3 .^{27,28}$

certain that every harvest loss in our data in 2001 was reported as a consequence of this draught. This then casts serious doubt on an alternative story of reverse causality in which the shock resulted as a consequence of less effort being expended on the household's farm after the departure of a family member.

${ }^{27}$ As we are clustering on municipios, our asymptotics are with respect to municipios, not households. Given that we are estimating a non-linear model, the inclusion of municpio dummies creates the famous incidental parameters problem of Neyman and Scott (1948) where the number or parameters increases with the sample size (the number of clusters). However, while inclusion of municpio dummies may not be appropriate on theoretical grounds, the parameter estimates are similar with and without the municipio dummies, thereby, suggesting that the incidental parameters problem is of little concern here.

${ }^{28}$ It is important to address the pros and cons of the location dummies. First, using municipio dummies, creates an efficiency loss since their inclusion relies on variation in shocks within municipios. All variation in the shocks across municipios gets absorbed by the location dummies. This is desirable as it addresses any concerns about correlations between shocks and location effects. However, it is undesirable since variation that occurs across municipios is potentially useful information that does not get utilized and this results in an efficiency loss. This is particularly undesirable as efficiency is not something that is relatively abundant in shorts panels with small sample sizes and noisy data. Indeed, it may be the case that the cure is worse than the sickness. Second, El Salvador is roughly the size of Massachusetts. El Salvador is divided into fourteen departments and 
Excluding stories involving non-random assignment of the shocks (which we consider later), the finding that the earthquakes had a negative impact on migration is consistent with two explanations. The first is that the earthquakes created exigencies which caused households to retain members at home or bring members back from the US in order to help the family recover from the disaster's effects. The second explanation is that the earthquakes were an enormous burden on the household's financial resources which prohibited the household from putting up the capital necessary to send members abroad. ${ }^{29}$ In Section 5, we investigate the role that liquidity constraints play in household's migration decisions and, in doing so, attempt to disentangle these explanations from one-another.

To give the reader some notion of the magnitude of these shocks, we calculate their marginal impacts. The results are in Table 8. Detail concerning how the marginal effects were calculated can be found in the appendix. We see that, in the absence of any agricultural shocks, the probability of sending members abroad in both years (northward migration) decreases from 0.2650 to 0.2007 - a $24.26 \%$ decrease. The probability of receiving members (southward migration) increases from 0.0914 to 0.1262 - a $38.07 \%$ increase. Turning to the earthquakes, we see that a one standard deviation increase in the level of damage lowers the probability of northward migration in 2001 from 0.2328 to 0.1464 - a $37.11 \%$ change. In contrast, the probability of southward migration goes from 0.1073 to 0.1682 - a $56.76 \%$ increase.

\subsection{The Impact of Shocks on Remittances}

Massachusetts is divided into fourteen counties. Consequently, we believe that it is reasonable to expect that department dummies may adequately control for location effects without incurring the same efficiency costs as the municpio dummies.

29 "Illegal" migration to the US from El Salvador typically requires payments to smugglers or coyotes that can exceed $\$ 1500$ (Menjívar 2000). 
We now turn to the effects of exogenous shocks in El Salvador on migrant remittances. Let $r_{h, t}$ denote the amount remitted by all migrants in household $h$ at time $t$ in logs and let $R_{h, t}$ denote remittances in levels. Using the notation from above for the other variables, we estimate the simple linear models

$$
r_{h, t}=\beta_{0}+\beta_{1} \omega_{h, t}+\beta_{2} X_{h, t}+\beta_{3} Z_{h, t-1}+u_{h, t}
$$

and

$$
\log \left(\frac{R_{h, t}}{M_{h, t}}\right)=\gamma_{0}+\gamma_{1} \omega_{h, t}+\gamma_{2} X_{h, t}+\gamma_{3} Z_{h, t-1}+v_{h, t}
$$

to identify the effects of exogenous shocks on migrant remittances. Equation (2) tells us the impact of shocks on total migrant remittances and equation (3) tells us the impact of shocks on remittances per migrant. Equation (3) is of interest as it is informative of cross-sectional risk sharing within spatially diversified households. In other words, it is suggestive of whether or not a given migrant remits more when their family at home experiences adversity. ${ }^{30}$

Table 9 reports the results. In the first column, we see that - consistent with Table 7 - that agricultural shocks are associated with higher remittances. However, the inclusion of the department and municipio dummies attenuates the impact of livestock loss and takes away the impact of harvest loss. Our estimates indicate that a livestock loss results in an increase in migrant remittances that is on the order of $40-60 \%$ whereas the first column suggests that households that experienced a harvest loss witnessed an increase in remittances on the order of $40 \%{ }^{31}$ In addition, we see that the earthquakes are associated with decreases in the total

\footnotetext{
${ }^{30}$ We also estimated the remittance equation using a standard Tobit model. The results are similar to the OLS results. In order to save space, the results are not reported, but they are available upon request. We attempted to use the Censored Least Absolute Deviations model of Powell (1984), but were unsuccessful as the remittance data contain too much censoring.

${ }^{31}$ See footnote 27 for a discussion of the pro and cons of location effects.
} 
amount remitted from the US. The elasticities of total migrant remittances with respect to earthquake damage in the first three columns are $-0.11,-0.06$, and -0.04 , respectively. Finally, the effects of the earthquakes in Table 9 remain significant after the department dummies are added suggesting that the marginally significant estimates in the last two columns of Table 7 were most likely the consequence of increased imprecision due to the addition of location effects.

The basic lesson that we learn in the first three columns of the table is that shocks affect total migrant remittances the same way that they affect migration - although, the results do become more imprecise with the addition of location effects. Agricultural shocks pushed people to the US and increased remittances, whereas the earthquakes pulled people back and decreased remittances. In this sense, the results in Table 9 reinforce those in Table 7.

The last two columns of Table 9 report the results of estimating equation (3). In both columns, we see that the agricultural shocks had positive impacts on remittances per migrant, although, when we include the department dummies, harvest loss is no longer significant. This is suggestive, but by no means conclusive, that, not only do households self-insure against agricultural shocks via migration (i.e.. changes in their migrant stocks across time), but also that households that are hit by agricultural shocks insure themselves in the cross-section via increases in intra-household transfers (i.e. changes in the amount remitted per migrant).

Turning to the effects of the earthquakes, we see negative and significant effects on remittances per migrant. This is interesting as it does not suggest that existing migrants remitted more in order to insure their families against the disaster's consequences as one would expect if the household were engaging in cross-sectional risk sharing through state-contingent transfers. One explanation for this coefficient is that households that were hit by the earthquakes valued the 
labor of potential and existing migrants more than they valued their remittances. However, a more plausible explanation is that households that were more likely to be affected by the earthquakes also received fewer remittances per migrant from abroad prior to their occurrence. In other words, earthquake damage may have been non-randomly assigned to households who were less likely to receive remittances. The next section discusses the implications of this for the core results of Table 7 and provides evidence that earthquake damage was most likely assigned non-randomly, but also that this was probably not responsible for the results in Table 7 .

This discussion highlights some of the pitfalls of OLS estimation of equations (2) and (3) to identify the impact of shocks on remittances. The first concerns potential correlation between the shocks and omitted household characteristics resulting from non-random assignment. One seemingly sensible remedy to this would be fixed-effects estimation. However, while it is true that fixed-effects estimation does address many problems concerning omitted variables, it comes with considerable efficiency loss. ${ }^{32}$ Consequently, given our data, we believe that the costs of fixedeffects estimation greatly outweigh its benefits. ${ }^{33}$ Another pitfall associated with estimation of the remittance equations concerns measurement error in remittances. While it is true that measurement error in dependent variables will only result in asymptotic biases if it is correlated with right-hand side variables, in finite samples it may still be problematic as it adds additional noise to our estimator that is only zero in a large sample.

\footnotetext{
${ }^{32}$ As pointed out by Deaton (1995), addressing unobserved heterogeneity is not free. For example, one important issue concerns the role that serial correlation in the agricultural shocks plays. If there is positive serial correlation (which there is in our data), demeaning results in a substantial loss of variation and, thus, greater imprecision. A second issue concerns the role of measurement error. Generally, demeaning will exacerbate the role of measurement error which, in the case of the agricultural shocks, should bias the estimates toward zero (see Aigner (1973) for a discussion of measurement error with binary regressors). These caveats are especially important to bear in mind given our small sample size and our short panel.

${ }^{33}$ We do have a set of fixed-effects results which are available upon request. These results, not surprisingly, are less precise. Nevertheless, they still paint a similar picture to what we have been seeing throughout this paper.
} 


\section{Alternative Explanations}

In this section, we explore some alternative explanations for the previous section's results. We consider the possibility that migration is used to hedge risk ex ante as opposed to ex post as well as the possibility that the shocks were assigned non-randomly to households with varying wealth levels and/or ties to the US. We also investigate the possibility that the previous section's results were, at least, in part the consequence of non-random attrition. We now discuss of these competing hypotheses.

Ex Ante Risk Management It is conceivable that the previous section's effects of the agricultural shocks are capturing the use of migration as an ex ante risk coping strategy. The reason for this is that households which are engaged in risky agricultural activities may also engage in migration as a means of hedging against risk prior to the occurrence of any shocks. This suggests that agricultural shocks were more likely to be assigned to households that engage in migration as opposed to households actually migrating in response to the shock.

Non-Random Assignment to Households with Weak Ties to the US The effects of the earthquakes on migration may be the consequence of the earthquakes disproportionately impacting households with weaker ties to the US as opposed to families utilizing household labor to buffer their effects. One might expect this to happen since much research has shown that migrant networks play important roles in the household's migration decision in the sense that households with migrants already residing in the US are more likely to send additional members 
abroad (see Massey et al. 1987 for a discussion). ${ }^{34}$

Non-Random Assignment to Poorer Households A similar concern to the previous one is that the earthquakes hit poorer households. ${ }^{35}$ This is potentially problematic if households are liquidity constrained, especially, given the large cost of migration. As a result, it could be the case that households that were hit by the earthquakes would not have migrated irrespective of whether or not they were affected by the earthquakes. ${ }^{36}$ While the exercises in this section shed some light on this issue, we provide a more thorough investigation in Section 5.

Non-Random Attrition Attrition can also play a pernicious role in the estimation. For the agricultural shocks, we would not expect much of a bias since the results of Section 2.5 did not reveal any relationship between the agricultural shocks and attrition. However, we did find some evidence that households that resided in areas that were hit hard by the earthquakes were also more likely to survive in the panel. This is worrisome given that Thomas, Frankenberg and Smith (2001) provide evidence that migration was a major cause of attrition in the Indonesian Family Life Survey. Taken together, this suggests that survivors were more likely to be hit by the earthquakes and, at the same time, less likely to migrate. This implies that our estimates of the impact of the earthquakes may be negatively biased due to non-random attrition. ${ }^{37}$

\footnotetext{
${ }^{34}$ Similar arguments can be made for the agricultural shocks with harvest and livestock losses being more likely to hit households with stronger network ties.

${ }^{35}$ This does appear to be the case in our data.

${ }^{36}$ Once again, similar arguments can be made for the agricultural shocks.

${ }^{37}$ To see this formally, let $s_{h, t} \in\{0,1\}$ be an indicator for whether or not a household has survived in the panel from $t-1$ to $t$. A value of unity denotes survival. The direction of bias in the estimates of equation (1) will depend on the sign of $E\left[s_{h, t} \omega_{h, t} \varepsilon_{h, t}\right]$. For the reasons stated above, we do not expect there to be much of a bias for the components of this expectation which correspond to the agricultural shocks. However, for Earthquake Damage, which we denote by $Q_{h, t}$, we expect to see $E\left[s_{h, t} Q_{h, t} \varepsilon_{h, t}\right]<0$.
} 
All of these explanations have to do with non-random assignment of the shocks. Consequently, investigating the plausibility of these alternative theories will involve testing whether or not the shocks were, in fact, randomly assigned. In addition, we can gauge the plausibility of these alternative stories by seeing if households that were affected by the shocks also had unobservable characteristics that made them more or less disposed to migration even in the absence of any shocks.

To start investigating these issues, we start out by looking into whether or not shocks are predicted by baseline household characteristics. In Table 10, we regress each of the three shocks on baseline characteristics from the 1997 survey. The characteristics that we use are the household's migrant level, land holdings, household size and the head's education. As we can see, the only significant predictor of harvest loss is household size with larger households being more likely to experience subsequent losses. However, the robustness of the agricultural shocks to demographic controls in the previous section suggests that this is of little concern. In the second column, we see that livestock loss is only predicted by the head's education with more educated households being less likely to experience livestock loss. It is important to emphasize that subsequent agricultural shocks are not predicted by the baseline number of migrants in the household as would be expected if households that were engaged in risky agricultural activities also engaged in migration to hedge against risk ex ante. In addition, this casts doubt on the alternative story where the agricultural shocks affected households with stronger ties to the US. Turning to the earthquakes, we see that households with less migrants abroad and with less land were more likely to be severely hit by the earthquakes. This raises some concern that households that were hit by the earthquakes would have been less likely to migrate irrespective 
of the disaster due to either the networks story or the liquidity constraints story. ${ }^{38}$

In Table 11, we further investigate the possibility that the results of the previous section are confounded by these alternative stories by looking at the relationship between "counter-factual" shocks and trends in migration and remittances. The counter-factual shocks that we employ are the 2001 shocks merged into the 1999 data and the 1999 shocks merged into the 2001 data. We do not use the actual shocks. In this exercise, we wish to test whether or not the shocks were assigned to households that would have made the same migration decision even if they had not been hit by the shock.

The first column of the table re-states the results from the second column of Table 7 as a benchmark. The second column is identical to the first except that now we use the counterfactual shocks. As can be seen, nothing is significant at conventional levels and, thus, there is no evidence in favor of the competing theories. The last two columns look at trends in remittances and remittances per migrant. The counter-factual shocks have no impact on neither trends in remittances nor trends in remittances per migrant. The results of this table do not suggest that the core results in Table 7 are the consequence of non-random assignment of shocks.

\section{Migration, Liquidity Constraints and Earthquakes}

The purpose of this section is twofold. Our primary objective is to further explore the role that liquidity constraints play in the household's migration decision. Our secondary objective is to provide additional robustness checks which are facilitated by this section's empirical framework.

\footnotetext{
${ }^{38}$ In the next section, we include all of the significant predictors of shocks in our regressions to ensure that our results are robust to non-random assignment. They are.
} 
Specifically, we have three concerns. The first and primary concern of this section is to better understand to what extent the 2001 earthquakes stunted migration as a consequence of the disruption of migration financing. Second, we want to ensure that the effects of the earthquakes on migration are not driven by the earthquakes disproportionately affecting poorer households who may have had a harder time financing migration. Finally, we also include all other regressors from Table 10 that significantly predicted shocks to ensure that the results of Table 7 are not being driven by non-random assignment. ${ }^{39}$

We work with a modification of equation (1). As we discussed earlier, one of the drawbacks of the ordered model is that it assumes that a covariate that has a positive effect on northward migration must have a negative effect on southward migration. This is an undesirable trait if a covariate of interest, such as land holdings, which serves as a proxy for household wealth, has a positive effect on northward as well as southward migration. To address this issue, we break the variable $\Delta M_{h, t}$ into two components: one that measures northward migration and one that measures southward migration. Formally, we define these two components as

$$
\begin{aligned}
\Delta M_{h, t}^{N} & =\Delta M_{h, t} * 1\left(\Delta M_{h, t} \geq 0\right) \\
\Delta M_{h, t}^{S} & =\Delta M_{h, t} * 1\left(\Delta M_{h, t} \leq 0\right) .
\end{aligned}
$$

\footnotetext{
${ }^{39}$ It will become apparent to the reader why we could not have done this with the empirical model in Section 3 .
} 
We then estimate the models

$$
\begin{gathered}
1\left(\Delta M_{h, t}^{S}=n\right)= \\
1\left(\alpha_{n-1}^{S} \leq \delta_{1}^{S} \omega_{h, t}+\delta_{2}^{S} X_{h, t}+\delta_{3}^{S} Z_{h, t-1}+\delta_{4}^{S} T_{h, t-1}+\delta_{5}^{S} T_{h, t-1}^{2}+\delta_{6}^{S} T_{h, t-1} * Q_{h, t}+\varepsilon_{h, t}^{S}<\alpha_{n}^{S}\right) \\
\text { for } n \in\{\ldots,-1,0\}
\end{gathered}
$$

and

$$
\begin{gathered}
1\left(\Delta M_{h, t}^{N}=n\right)= \\
1\left(\alpha_{n-1}^{N} \leq \delta_{1}^{N} \omega_{h, t}+\delta_{2}^{N} X_{h, t}+\delta_{3}^{N} Z_{h, t-1}+\delta_{4}^{N} T_{h, t-1}+\delta_{5}^{N} T_{h, t-1}^{2}+\delta_{6}^{N} T_{h, t-1} * Q_{h, t}+\varepsilon_{h, t}^{N}<\alpha_{n}^{N}\right) \\
\text { for } n \in\{0,1, \ldots\}
\end{gathered}
$$

where $T_{h, t}$ is the total land holdings of the household and $Q_{h, t}$ is the earthquake damage index. ${ }^{40}$ The land variable that we use is Land 1, although, at the end of this section, we also check to ensure that our results are robust to alternative measures. $\omega_{h, t}$ is defined as in Section 3. We use lags of the household's land holdings to account for the fact that migration today may have a contemporaneous impact on land transactions. In some of the specifications, we also include the household's migrant stock and the education of the household head from the 1997 data (both of which significantly predicted some of the shocks in Table 10) as a final robustness check. ${ }^{41}$ Table 12 reports the results for southward migration and Table 13 reports the results

\footnotetext{
${ }^{40}$ It is important to note that these models estimate the impact of shocks on net northward or southward migration.

${ }^{41}$ The impact of the 1997 migrant stock on migration in 1999 and 2001 is similar to the impact of land holdings in the sense that it has a positive impact on northward migration and a negative impact on southward migration. Accordingly, to assess the impact of the migrant stock it is essential that you break the migration variable into northward and southward components.
} 
for northward migration.

The coefficients $\delta_{4}^{j}$ and $\delta_{5}^{j}$ for $j \in\{S, N\}$ warrant some discussion. They are informative the impact of wealth on the household's migration decision. If migration is more common among wealthier households then we will see that $\delta_{4}^{N}>0$ and $\delta_{4}^{S}<0 .{ }^{42}$ While this would be consistent with the presence of liquidity constraints, there are certainly alternative reasons for a positive relationship between land holdings and migration. ${ }^{43}$ Consequently, a positive relationship between wealth and migration should be interpreted as suggestive but by no means conclusive evidence that liquidity constraints matter. The coefficients $\delta_{5}^{j}$ for $j \in\{S, N\}$ allow for non-linearities in the relationship between wealth and migration.

The coefficients $\delta_{6}^{j}$ for $j \in\{S, N\}$ allow the impact of an earthquake shock of a given size to vary with the household's wealth level. This interaction is important because the presence of liquidity constraints implies that, for example, $\$ 500$ worth of damage will have a much greater impact on a household's ability to finance migration when they have no assets than when they have $\$ 10,000$ worth of assets. Thus, if the earthquakes disrupted migration because they affected migration financing then we would expect to see that $\delta_{6}^{N}>0$ since this would mean that the earthquakes would have stunted migration for poorer households, who are more likely to face liquidity constraints, more than they stunted migration for richer households, who are less likely to face liquidity constraints. Turning to equation (4), if the household in El Salvador finances the migrant's return trip and if the earthquakes stunted migration as a consequence of liquidity constraints, then we would expect to see that $\delta_{6}^{S}<0$, since poorer households that were affected

\footnotetext{
${ }^{42}$ When the dependent variable is southward migration, a positive (negative) coefficient means that the variable has a negative (positive) effect on southward migration.

${ }^{43}$ For example, households with large land holdings may also be more likely to be engaged in risky agricultural activities and, hence, more likely to use migration (either ex post or ex ante) to mitigate the impact of income shocks.
} 
by the earthquakes would have been less able to pay the migration costs to bring household members back from the US. However, since, anecdotally, we would expect the migrant and not the family back home to finance return migration, we do not expect $\delta_{6}^{S}$ to be that informative of the interaction between liquidity constraints and the earthquakes.

In Table 12, we see that household wealth, as proxied by land holdings, is positively associated with southward migration. The estimates of $\delta_{4}^{S}$ are negative and highly significant. So, we see that wealthier households are more apt to have members migrate back from the US. ${ }^{44}$ In columns 3 and 5 of the table, we see substantial evidence of non-linearities in the wealth-migration relationship as shown by the positive and significant estimates of $\delta_{5}^{S} .{ }^{45}$ This may be suggestive that sufficiently wealthy households do not need to rely on migration for supplemental income or informal insurance.

Table 12 does not provide evidence that any of the shocks directly affect southward migration. However, it is interesting to note that in column 2, when we exclude the year dummy, the earthquakes do have a significant effect on southward migration. Because southward migration is not that frequent in our data, this may reflect a difficulty disentangling the effects of the earthquakes from the year effect. ${ }^{46}$

The estimate of $\delta_{6}^{S}$ in Table 12 is essentially zero in column 4 , but is positive with a $t$-statistic of unity in column 5 once we allow for a quadratic in land holdings. This is interesting for

\footnotetext{
${ }^{44}$ If we use household savings in lieu of land, we see that savings is also positively associated with southward migration.

${ }^{45}$ The positive effects of land holdings on migration that we observe in this section are consistent with empirical results in Hoddinott (1994) in his analysis of migration in Kenya.

${ }^{46} \mathrm{~A}$ total of 141 households experienced southward migration in either 1999 or 2001. 95 of these households experienced southward migration in 2001. Of these 95 households, 56 experienced some earthquake damage. We believe that it is reasonable to expect that these small number make it difficult to disentangle the earthquakes from the year effect in Table 12 .
} 
two reasons. First, as argued above, if the earthquakes stunted migration as a consequence of liquidity constraints and if the household in El Salvador finances return migration (a big if) then we would expect to see a negative estimate which we do not see. Second, the positive (but imprecise) estimate of the interaction suggests that southward migration, as a consequence of the earthquakes, was more likely for poorer households than for richer households. What this suggests is that wealthier households may have had alternative means at their disposal of buffering the shock of the earthquakes other than bringing back family members from the US. Finally, this provides additional evidence that the earthquakes may have induced southward migration, although, these effects appear to be concentrated among the poor. ${ }^{47}$

We now turn to Table 13 and look at the effects of land holdings on northward migration. In the table, we see that the estimates of $\delta_{4}^{N}$ are all positive and highly significant so that more wealth is associated with northward migration. ${ }^{48}$ Once again, the results suggest that liquidity constraints may be an important determinant of households' ability to send members abroad. However, we must stress once again that a positive relationship between migration and land holdings is only suggestive of the presence of liquidity constraints. Completely analogous to Table 12, the estimates of $\delta_{5}^{N}$ are all negative and significant suggesting non-linearities in the migration/wealth relationship. Finally, the estimates of $\delta_{6}^{N}$ in columns 3,4 and 5 are very close to zero and not significant. As argued above, this is not what we would have expected to see if the earthquakes stunted migration as a consequence of liquidity constraints. ${ }^{49}$

\footnotetext{
${ }^{47}$ The fact that we find some, albeit tenuous, evidence of southward migration due to the earthquakes sheds an interesting light on whether the earthquakes stunted migration as a consequence of credit constraints or increased demand for labor at home. The reason for this is that if the only effect of the earthquakes was to disrupt migration financing, then we would not expect to see any evidence of reverse migration due to earthquake damage.

${ }^{48}$ If we use savings in lieu of land holdings, we see that savings has a positive effect on northward migration.

${ }^{49} \mathrm{An}$ important issue concerning our tests for the importance of liquidity constraints is the presence of mea-
} 
In addition, Table 16 shows that the effects of exogenous shocks on northward migration are broadly consistent with the results in Table 7 . We see that households that received adverse agricultural shocks were more likely to experience northward migration. In addition, the table shows that households that were severely affected by the earthquakes were less apt to send members to the US. The fact that the earthquakes are robust to the inclusion of land holdings is important because it addresses a concern of Section 4 in which land holdings predicted earthquake damage.

Another concern that was raised in Section 4 was that baseline migrants also predicted earthquake damage and that baseline education predicted livestock loss. To address this, the fourth and fifth columns of the table add baseline migrants and education as controls. In column 4, we add baseline migrants. We see that, while there is a positive relationship between the household's migrant stock in 1997 and subsequent migration, which we would expect if networks matter, the point-estimate on earthquake damage remains unchanged and significant. Overall, this table does not lend any support to the alternative explanations concerning migrant networks that were raised in Section 4. In column 5, we include both baseline migrants and baseline education. While it is true that livestock loss is no longer significant, it was also not significant in column 4 when baseline education was not included. Consequently, the lower point-estimate on livestock loss in columns 4 and 5 probably has more to do with the sample size being reduced by 100 observations than with the inclusion of baseline education. ${ }^{50}$

surement error in both land holdings and damage. In a linear model, classical measurement error will result in attenuation bias with the degree of attenuation increasing with the $R^{2}$ of the short regression of the interaction term on the remaining covariates. However, in our case, the estimate of $\delta_{6}^{S}$ is negative which is not consistent with attenuation bias due to classical measurement errors. Nevertheless, the assumptions of classical measurement error are quite restrictive and it is conceivable that a more complex form of measurement is operating in our estimation. Unfortunately, it is difficult to assess the plausibility of this scenario without alternative measures of Earthquake Damage as well as all three land measures.

${ }^{50}$ The results in Table 10 suggested that earthquake damage may not have been randomly assigned to house- 
Finally, in Table 14, we ensure that our results are robust to different measures of land holdings. We report the coefficients on land, land squared and the interaction of land and earthquake damage using the three measures of land that are described in Section 2. As can be seen in the table, our conclusions are not impacted in any way by our choice of land measure.

\section{Conclusions}

This paper investigated the relationship between idiosyncratic economic shocks in El Salvador and migrant flows to the US. To accomplish this, we utilized panel data from El Salvador that contained good measures of economic shocks and migrant flows. Our results indicate that migration to the US is, in part, determined by the economic conditions which prevail in El Salvador. Overall, this paper paints a picture in which Salvadoran households use migration as an ex post risk management strategy.

We showed that adverse agricultural conditions in El Salvador tended to push household members to the US. In the absence of any shocks, the average probability that a household sends members abroad decreases by $24.26 \%$. In addition, we provide evidence that the effects of agricultural shocks on migration are accompanied by increases in remittances that are on the order of $40 \%-60 \%$.

In contrast, we showed that households that were affected by the 2001 earthquakes tended to

holds. One of our strategies to address this concern was to add the significant predictors of damage as controls and check if damage was still significant. This technique comes from the literature on treatment effects. The idea is that provided that the outcome (migration) is independent of the treatment (damage) conditional on a set of covariates that predict treatment, the econometrician can identify the true impact of the treatment on the outcome by regressing the outcome on the treatment and all covariates that predict the treatment. This is what Wooldridge (2000) refers to as a "kitchen sink regression." For an excellent overview of treatment effects using binary treatments, see Wooldridge (2000). 
retain members at home. A one standard deviation increase in earthquake damage lowers the average probability that a household sends someone to the US by $37.11 \%$. One explanation for this is that households retained labor at home to deal with the aftermath of the disaster. This explanation states that the labor of household members was used to buffer the earthquake's effects. Another explanation for this result is that Salvadoran households are liquidity constrained and that the earthquakes disrupted household finances which would have otherwise been used to finance migration.

To disentangle these two explanations from one-another, we investigated the nexus of migration, wealth and the earthquakes. First, we showed that migration is more likely for wealthier households suggesting that liquidity constraints are important. However, we also showed that the earthquakes were just as likely to stunt migration for wealthier households as they were for poorer households which is not consistent with the story in which the earthquakes stunted migration because they disrupted migration financing.

Finally, an important topic which warrants additional work concerns the degree of crosssectional risk sharing that occurs between migrants and home dwellers via remittances. This topic is challenging as it is very difficult to identify the direct effect that adverse shocks will have on remittances. The reason is that shocks will affect remittances both directly and indirectly. The direct effect corresponds to cross-sectional risk pooling. The indirect effect corresponds to households using migration as a self-insurance mechanism, which is the focus of this paper. In the absence of the stringent distributional assumptions that would be imposed by a complicated structural model, identification would entail using instruments which affect migration but do not affect remittances. Finding valid instruments is likely to be difficult if not impossible. Hence, 
progress on this front most likely will need to rely on structure and, of course, better data. Another reason why this topic is challenging concerns the role that imperfect information would play in risk pooling arrangements. As discussed by Rosenzweig (1988), the large distances that can separate migrants from their families are likely to amplify the role that asymmetric information will play in intra-family risk sharing arrangements.

\section{Appendix 1 - Calculating the Marginal Impact of Shocks}

We now provide the details concerning the calculation of the marginal effects in Table 9 . Let $\omega_{h, t}$ denote the shock vector as defined in Section 3. Let $\omega_{h, t}^{A}$ have the same values for the earthquake shocks as in $\omega_{h, t}$, but have no agricultural disturbances. So, Harvest Loss and Livestock Loss always equal zero in $\omega_{h, t}^{A}$. Alternatively, let $\omega_{h, t}^{Q}$ have the same values for the agricultural shocks as $\omega_{h, t}$, but have a one standard increase in the level of earthquake damage. We then computed the fitted probabilities from equation (1) using the specification in column 2 of Table 7 using $\omega_{h, t}$, $\omega_{h, t}^{A}$ and $\omega_{h, t}^{Q}$. Let $p_{h, t}\left(\Delta M_{h, t}=n \mid x\right)$ for $x \in\left\{\omega_{h, t}, \omega_{h, t}^{A}, \omega_{h, t}^{Q}\right\}$ denote the estimated probability that net migration in household $h$ at time $t$ equals $n$ evaluated at $\omega_{h, t}, \omega_{h, t}^{A}$ or $\omega_{h, t}^{Q}$. Then, the probability of northward migration (out-migration) for a household is given by

$$
p_{h, t}\left(\Delta M_{h, t}>0 \mid x\right)=\sum_{n>0} p\left(\Delta M_{h, t}=n \mid x\right) \text { for } x \in\left\{\omega_{h, t}, \omega_{h, t}^{A}, \omega_{h, t}^{Q}\right\}
$$

and the probability of southward migration (in-migration) is given by

$$
p_{h, t}\left(\Delta M_{h, t}<0 \mid x\right)=\sum_{n<0} p\left(\Delta M_{h, t}=n \mid x\right) \text { for } x \in\left\{\omega_{h, t}, \omega_{h, t}^{A}, \omega_{h, t}^{Q}\right\}
$$


The average probability of out-migration is then given by

$$
p\left(\Delta M_{h, t}>0 \mid x\right)=(H T)^{-1} \sum_{h, t} p_{h, t}\left(\Delta M_{h, t}>0 \mid x\right)
$$

and the average probability of in-migration is then given by

$$
p\left(\Delta M_{h, t}<0 \mid x\right)=(H T)^{-1} \sum_{h, t} p_{h, t}\left(\Delta M_{h, t}<0 \mid x\right)
$$

To calculate the marginal impact of the agricultural shocks, we then computed the average probabilities in (8) and (9) for all households who experienced either a harvest loss or a livestock loss evaluated at $\omega_{h, t}$. We then calculated these probabilities again for the same households under the assumption that they did not experience any agricultural shocks i.e. using $\omega_{h, t}^{A}$. To calculate the marginal impact of the earthquakes, we computed (8) and (9) for all households in 2001 using $\omega_{h, t}$ and then again using $\omega_{h, t}^{Q}$.

\section{References}

[1] Aigner, Dennis J. 1973. "Regression with a Binary Independent Variable Subject to Errors of Observation," Journal of Econometrics 1 (1): 49-50.

[2] Besley, Timothy. 1995. "Savings, Credit and Insurance." In Handbook of Development Economics, Volume 3A, ed. Jere Behrman and T.N. Srinivasan. Amsterdam: North Holland.

[3] Deaton, Angus. 1992. Understanding Consumption. Oxford: Oxford University Press. 
[4] Deaton, Angus. 1995. "Data and Econometric Tools for Development Analysis." In Handbook of Development Economics, Volume 3A, ed. Jere Behrman and T.N. Srinivasan. Amsterdam: North Holland.

[5] Deaton, Angus. 1997. The Analysis of Household Surveys: A Microeconometric Approach to Development Policy. Baltimore: The Johns Hopkins University Press.

[6] Fitzgerald, John, Peter Gottschalk and Robert Moffitt, 1998, "An Analysis of Sample Attrition in Panel Data." Journal of Human Resources 33 (2): 251-299.

[7] Hoddinott, John. 1994. "A Model of Migration and Remittances Applied to Western Kenya." Oxford Economic Papers 46 (3): 459-476.

[8] Massey, Douglas S., Rafael Alarcon, Jorge Durand, and Humberto Gonzalez. 1987. Return to Aztlan: The Social Process of International of International Migration from Western Mexico. Berkeley: University of California Press.

[9] Menjívar, Cecilia. 2000. Fragmented Ties: Salvadoran Immigrant Networks in America. Berkeley: University of California Press.

[10] Ministerio de Relaciones Exteriores (MRE). 2001. Resumen Ejecutivo Sobre Salvadoreños en el Exterior.

[11] Moffitt, Robert, John Fitzgerald, and Peter Gottschalk. 1999. "Sample Attrition in Panel Data: The Role of Selection on Observables." Annale d'Economie et de Statistique. 0 (55/56): 129-152. 
[12] Munshi, Kaivan. 2003. "Networks in the Modern Economy: Mexican Migrants in the US Labor Market." Quarterly Journal of Economics 118 (2): 549-599.

[13] Neyman, J, and Elizabeth Scott. 1948. "Consistent Estimates Based on Partially Consistent Observations." Econometrica 16 (1): 1-32.

[14] Nicolás, Nestor A. and Richard S. Olson. 2001. "'SUMA' and the 2001 El Salvador Earthquakes: An Independent External Evaluation." Submitted to the Pan-American Health Organization, July 1, 2001.

[15] Paulson, Anna L. 2000. "Insurance and Migration: Evidence from Thailand." Unpublished manuscript, University of Chicago, Department of Economics.

[16] Paxson, Christina H. 1992. "Using Weather Variability to Estimate the Response of Savings to Transitory Income in Thailand." American Economic Review. 82 (1): 15-33.

[17] Powell, James L. 1984. "Least Absolute Deviations Estimation of the Censored Regression Model." Journal of Econometrics 25 (3): 303-325.

[18] Programa de las Naciones Unidas de Desarollo (PNUD). 2001. Informe Sobre Desarollo Humano. El Salvador: Programa de las Naciones Unidas de Desarollo.

[19] Ravallion, Martin and Shubham Chaudhuri. 1997. "Risk and Insurance in Village India: Comment." Econometrica. 65 (1): 171-184.

[20] Rosenzweig, Mark R.. 1988. "Risk, Implicit Contracts and the Family in Rural Areas of Low-Income Countries." Economic Journal 98 (393): 1148-1170. 
[21] Rosenzweig, Mark R. and Oded Stark. 1989. "Consumption Smoothing, Migration and Marriage: Evidence from Rural India." Journal of Political Economy 97 (4): 905-926.

[22] Rosenzweig, Mark R. and Kenneth L. Wolpin. 1993. "Credit Market Constraints, Consumption Smoothing, and the Accumulation of Durable Production Assets in Low-Income Countries: Investment in Bullocks in Inida." Journal of Political Economy 101 (2): 223-244.

[23] Ruggles, Steven, Mathew Sobek, Trent Alexander, Catherine A. Fitch, Ronald Goeken, Patrica Kelly Hall, Miriam King and Chad Ronnander. 2004. Integrated Public Use Microdata Series, Version 3.0. Minneapolis: Minnesota Population Center.

[24] Thomas, Duncan, Elizabeth Frankenberg and James P. Smith. 2001. "Lost but not Forgotten: Attrition and Follow-up in Indonesian Family Life Survey." Journal of Human Resources 36 (3): 556-592.

[25] Townsend, Robert M. 1994. "Risk and Insurance in Village India." Econometrica. 62 (3): $539-591$.

[26] Udry, Christopher. 1994a. "Risk and Insurance in a Rural Credit Market: An Empirical Investigation in Northern Nigeria." Review of Economic Studies 61 (3): 495-526.

[27] Udry, Christopher. 1994b. "Risk and Saving in Northern Nigeria" American Economic Review 85 (5): 1287-1300.

[28] Wooldridge, Jeffrey M. 2000. Econometric Analysis of Cross Section and Panel Data. Cambridge, MA: MIT Press. 
8 Tables 
Table 1: Variables

\begin{tabular}{|c|c|c|}
\hline Variable & Definition & $\begin{array}{c}\text { Mean } \\
\text { (Standard } \\
\text { Deviation) }\end{array}$ \\
\hline Migrants $^{1}$ & $\begin{array}{l}\text { the number of household members } \\
\text { residing in the US }\end{array}$ & $\begin{array}{c}0.55 \\
(1.23)\end{array}$ \\
\hline Remittances $^{1,3}$ & $\begin{array}{l}\text { total amount remitted by all migrants in } \\
\text { the household in } 1992 \text { dollars }\end{array}$ & $\begin{array}{c}303.29 \\
(974.22)\end{array}$ \\
\hline Land $1^{1}$ & $\begin{array}{l}\text { the total land holdings in manzanas of the } \\
\text { household that has either a title or documents } \\
\text { indicating the power of transfer }\end{array}$ & $\begin{array}{c}1.69 \\
(5.38)\end{array}$ \\
\hline Land $2^{1}$ & $\begin{array}{l}\text { the total land holdings in manzanas of the } \\
\text { household that has either a title, documents } \\
\text { indicating the power of transfer or no official } \\
\text { documents }\end{array}$ & $\begin{array}{l}1.82 \\
(5.59)\end{array}$ \\
\hline Land $3^{1}$ & $\begin{array}{l}\text { the total land holdings in manzanas of the } \\
\text { household that has a title }\end{array}$ & $\begin{array}{l}1.63 \\
(5.39)\end{array}$ \\
\hline Harvest Loss ${ }^{2}$ & dummy indicating income loss due to harvest loss & $\begin{array}{c}0.19 \\
(0.39)\end{array}$ \\
\hline Livestock Loss $^{2}$ & dummy indicating income loss due to harvest loss & $\begin{array}{c}0.11 \\
(0.31)\end{array}$ \\
\hline Earthquake Damage ${ }^{3,4}$ & $\begin{array}{l}\text { the cost of all household damage due to the } 2001 \\
\text { earthquakes in } 1992 \text { dollars (in levels) }\end{array}$ & $\begin{array}{c}3261.15 \\
(9127.22)\end{array}$ \\
\hline Head's Education ${ }^{5}$ & Years of Education for the HH Head & $\begin{array}{l}2.78 \\
(3.14)\end{array}$ \\
\hline \multicolumn{3}{|c|}{${ }^{1}$ These descriptive statistics correspond to the years 1997, 1999, 2001.} \\
\hline \multicolumn{3}{|c|}{${ }^{2}$ These descriptive statistics correspond to the years 1999 and 2001.} \\
\hline \multicolumn{3}{|c|}{${ }^{3}$ These variables were deflated using the Salvadoran CPI. } \\
\hline${ }^{4}$ These descriptive statistic & nly correspond to 2001. & \\
\hline
\end{tabular}


Table 2: Sample Sizes by Year

Number of Households

\begin{tabular}{|c|c|}
\hline Households present in 2001, & 689 \\
\hline — present in 1999 and present in 1997 & 572 \\
\hline — present in 1999 and absent in 1997 & 100 \\
\hline - absent in 1999 and present in 1997 & 1 \\
\hline — absent in 1999 and absent in 1997 & 16 \\
\hline Households present in 1999 & 696 \\
\hline - present in 2001 and present in 1997 & 572 \\
\hline — present in 2001 and absent in 1997 & 100 \\
\hline — absent in 2001 and present in 1997 & 21 \\
\hline - absent in 2001 and absent in 1997 & 3 \\
\hline Households present in 1997 & 623 \\
\hline — present in 2001 and present in 1999 & 572 \\
\hline - present in 2001 and absent in 1999 & 1 \\
\hline - absent in 2001 and present in 1999 & 21 \\
\hline — absent in 2001 and absent in 1999 & 29 \\
\hline
\end{tabular}


Table 3: The Distribution of Agricultural Shocks

\begin{tabular}{c||ccc} 
Agricultural Shock & All Years & 1999 & 2001 \\
\hline \hline Number of Shocks & \multicolumn{3}{c}{445} \\
\multicolumn{1}{c||}{0} & 1025 & 580 & $(64.59 \%)$ \\
\multicolumn{1}{c}{$=1$} & $(74.01 \%)$ & $(83.33 \%)$ & 212 \\
& 314 & 102 & $(30.77 \%)$ \\
$=2$ & $(22.67 \%)$ & $(14.66 \%)$ & 32 \\
& 46 & 14 & $(4.64 \%)$ \\
\hline Harvest Loss & $(3.32 \%)$ & $(2.01 \%)$ & 515 \\
$=0$ & 1128 & 613 & $(74.75 \%)$ \\
& $(81.44 \%)$ & $(88.07 \%)$ & 174 \\
& 257 & 83 & $(25.25 \%)$ \\
\hline Livestock Loss & $(18.56 \%)$ & $(11.93 \%)$ & 587 \\
$=0$ & 1236 & 649 & $(85.20 \%)$ \\
& $(89.24 \%)$ & $(93.25 \%)$ & 102 \\
$=1$ & 149 & 47 & $(14.80 \%)$
\end{tabular}

*This table reports the frequency of adverse agricultural events. The top panel shows the distribution of households sustaining either harvest loss, livestock loss or both. The middle panel shows the distribution of households sustaining harvest loss. The bottom panel shows the distribution of households sustaining livestock loss.

${ }^{* *}$ The top number in each cell corresponds to the number of households sustaining the shock and the bottom number in each cell in parentheses corresponds to the percentage of households sustaining the shock. 
Table 4: Summary of Earthquake Damage

\begin{tabular}{l|cc}
\multicolumn{1}{c|}{ Type of Damage } & Average Cost ${ }^{1,2}$ & $\begin{array}{c}\text { Percentage of } \\
\text { Households Affected }\end{array}$ \\
\hline \hline House Destroyed & 868.94 & $10.3 \%$ \\
House Uninhabitable & 767.92 & $6.7 \%$ \\
Major House Damage & 777.79 & $14.6 \%$ \\
Minor House Damage & 279.11 & $28.0 \%$ \\
Other Edifices & 134.76 & $3.8 \%$ \\
Land & 143.82 & $1.7 \%$ \\
Furniture & 61.00 & $8.0 \%$ \\
Appliances & 193.12 & $11.0 \%$ \\
Tools Used for Agricultural Production & 1.71 & $0.01 \%$ \\
Machines Used for Agricultural Production & 0.68 & $0.001 \%$ \\
Tools Used for Non-agricultural Production & 2.27 & $0.01 \%$ \\
Machines Used for Non-agricultural Production & 20.21 & $0.01 \%$ \\
Merchandise Meant to be Sold & 11.19 & $0.02 \%$ \\
Stored Grains & 11.74 & $0.02 \%$
\end{tabular}

${ }^{1}$ All figures have been deflated using the Salvadoran CPI with 1992 as the base year.

${ }^{2}$ All figures are in dollars. 
Table 5: Demographic Characteristics

\begin{tabular}{l|ccc} 
Age Bracket & Men & Women & Test of Equality $^{1}$ \\
\hline \hline \multirow{2}{*}{$<=5$} & 0.38 & 0.38 & 0.02 \\
6 to 10 & $(0.67)$ & $(0.68)$ & $p=0.900$ \\
& 0.43 & 0.45 & 0.60 \\
11 to 15 & $(0.69)$ & $(0.69)$ & $p=0.437$ \\
& 0.41 & 0.41 & 0.00 \\
16 to 20 & $(0.67)$ & $(0.67)$ & $p=0.981$ \\
& 0.38 & 0.37 & 0.64 \\
21 to 40 & $(0.65)$ & $(0.63)$ & $p=0.423$ \\
& 0.63 & 0.75 & 31.38 \\
41 to 60 & $(0.75)$ & $(0.69)$ & $p=0.000$ \\
& 0.45 & 0.48 & 3.34 \\
$>60$ & $(0.52)$ & $(0.51)$ & $p=0.068$ \\
& 0.28 & 0.19 & 66.59 \\
& $(0.47)$ & $(0.41)$ & $p=0.000$
\end{tabular}

*The table reports descriptive statistics for number of household members at home in El Salvador within certain age and gender brackets for the years 1997, 1999 and 2001. Standard errors are reported in parentheses.

${ }^{1}$ The column reports an $F$-test of the equality of means for men and women. $p$-values are reported each $F$-statistic. 


\begin{tabular}{|c|c|c|c|c|}
\hline & $\begin{array}{c}\text { Table 6: Pane } \\
\text { Survival } \\
1997-2001 \\
\end{array}$ & $\begin{array}{l}\text { Attrition } \\
\quad \text { Survival } \\
1997-2001 \\
\end{array}$ & $\begin{array}{c}\text { Survival } \\
1999-2001\end{array}$ & $\begin{array}{c}\text { Survival } \\
1997-1999\end{array}$ \\
\hline Land & $\begin{array}{l}0.003 \\
(2.16)\end{array}$ & $\begin{array}{l}0.003 \\
(2.25)\end{array}$ & $\begin{array}{l}0.001 \\
(1.75)\end{array}$ & $\begin{array}{l}0.002 \\
(1.45)\end{array}$ \\
\hline Dummy Land $>0$ & $\begin{array}{c}0.02 \\
(0.74)\end{array}$ & $\begin{array}{c}0.02 \\
(0.61)\end{array}$ & $\begin{array}{c}0.03 \\
(1.91)\end{array}$ & $\begin{array}{c}0.02 \\
(0.90)\end{array}$ \\
\hline Migrants & $\begin{array}{l}-0.01 \\
(-0.67)\end{array}$ & $\begin{array}{c}-0.01 \\
(-0.50)\end{array}$ & $\begin{array}{c}-0.01 \\
(-1.99)\end{array}$ & $\begin{array}{c}-0.01 \\
(-0.94)\end{array}$ \\
\hline Head's Education & $\begin{array}{c}0.00 \\
(0.52)\end{array}$ & $\begin{array}{c}0.00 \\
(0.69)\end{array}$ & $\begin{array}{c}0.00 \\
(0.53)\end{array}$ & $\begin{array}{c}0.00 \\
(0.87)\end{array}$ \\
\hline Harvest Loss in 1999 & - & - & $\begin{array}{c}-0.01 \\
(-0.40)\end{array}$ & - \\
\hline Livestock Loss in 1999 & - & - & $\begin{array}{c}0.01 \\
(0.59)\end{array}$ & - \\
\hline$\%$ of Harvest Losses in Mun. ${ }^{1}$ & $\begin{array}{l}-0.07 \\
(-0.90)\end{array}$ & $\begin{array}{c}-0.03 \\
(-0.32)\end{array}$ & - & $\begin{array}{c}0.05 \\
(0.82)\end{array}$ \\
\hline$\%$ of Livestock Losses in Mun. ${ }^{1}$ & $\begin{array}{c}0.14 \\
(1.01)\end{array}$ & $\begin{array}{c}0.15 \\
(1.06)\end{array}$ & - & $\begin{array}{l}-0.02 \\
(-0.14)\end{array}$ \\
\hline Mean Quake Damage in Mun. ${ }^{1}$ & $\begin{array}{c}0.01 \\
(1.50)\end{array}$ & $\begin{array}{c}0.01 \\
(0.88)\end{array}$ & $\begin{array}{c}0.00 \\
(0.11)\end{array}$ & $\begin{array}{c}0.01 \\
(1.52)\end{array}$ \\
\hline Single Household Dummy? & $\begin{array}{l}-0.21 \\
(-1.25)\end{array}$ & $\begin{array}{l}-0.22 \\
(-1.24)\end{array}$ & $\begin{array}{l}-0.09 \\
(-0.91)\end{array}$ & $\begin{array}{c}-0.07 \\
(-0.63)\end{array}$ \\
\hline Household Size & $\begin{array}{l}-0.00 \\
(-0.68)\end{array}$ & - & - & - \\
\hline $\begin{array}{l}\text { Demographics Included } ?^{2} \\
\text { Department Dummies }\end{array}$ & $\begin{array}{l}\text { No } \\
\text { No }\end{array}$ & $\begin{array}{l}\text { Yes } \\
\text { Yes }\end{array}$ & $\begin{array}{l}\text { Yes } \\
\text { No }\end{array}$ & $\begin{array}{l}\text { Yes } \\
\text { Yes }\end{array}$ \\
\hline F-Test on Agriculture Shocks ${ }^{3}$ & $\begin{array}{c}0.73 \\
p=0.484\end{array}$ & $\begin{array}{c}0.56 \\
p=0.574\end{array}$ & $\begin{array}{c}0.33 \\
p=0.722\end{array}$ & $\begin{array}{c}0.36 \\
p=0.702\end{array}$ \\
\hline F-Test on All Shocks ${ }^{3}$ & $\begin{array}{c}1.25 \\
p=0.295\end{array}$ & $\begin{array}{c}0.63 \\
p=0.595\end{array}$ & $\begin{array}{c}0.26 \\
p=0.853\end{array}$ & $\begin{array}{c}0.98 \\
p=0.406\end{array}$ \\
\hline $\begin{array}{l}R^{2} \\
\text { Households }\end{array}$ & $\begin{array}{c}0.0177 \\
623\end{array}$ & $\begin{array}{c}0.0546 \\
623\end{array}$ & $\begin{array}{c}0.041 \\
696\end{array}$ & $\begin{array}{c}0.0580 \\
623\end{array}$ \\
\hline
\end{tabular}

*All standard errors allow for clustering within municipios.

${ }^{*} t$-statistics in parentheses.

${ }^{1}$ For details concerning the construction of these variables, see section 2.5.

${ }^{2}$ For details concerning the construction of these variables, see section 2.3 or footnote 1 of Table 7 .

${ }^{3} p$-values are reported below each $F$-statistic. 
Table 7: Migratory Responses to Adverse Shocks

\begin{tabular}{|c|c|c|c|c|c|}
\hline & $(1)$ & $(2)$ & (3) & (4) & (5) \\
\hline Harvest Loss & $\begin{array}{c}0.31 \\
(1.89)\end{array}$ & $\begin{array}{c}0.31 \\
(1.87)\end{array}$ & $\begin{array}{c}0.33 \\
(1.99)\end{array}$ & $\begin{array}{c}0.27 \\
(1.62)\end{array}$ & $\begin{array}{c}0.24 \\
(1.20)\end{array}$ \\
\hline Livestock Loss & $\begin{array}{c}0.36 \\
(1.84)\end{array}$ & $\begin{array}{c}0.36 \\
(1.86)\end{array}$ & $\begin{array}{c}0.37 \\
(1.94)\end{array}$ & $\begin{array}{c}0.38 \\
(1.95)\end{array}$ & $\begin{array}{c}0.46 \\
(2.26)\end{array}$ \\
\hline Earthquake Damage & $\begin{array}{l}-0.05 \\
(-2.15)\end{array}$ & 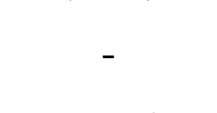 & $\begin{array}{c}-0.04 \\
(-1.80)\end{array}$ & $\begin{array}{l}-0.03 \\
(-1.33)\end{array}$ & $\begin{array}{l}-0.04 \\
(-1.44)\end{array}$ \\
\hline Earthquake Damage Dummy & - & $\begin{array}{l}-0.26 \\
(-1.54)\end{array}$ & - & - & - \\
\hline 2001 Dummy & $\begin{array}{l}-0.28 \\
(-1.55)\end{array}$ & $\begin{array}{l}-0.33 \\
(-1.76)\end{array}$ & $\begin{array}{l}-0.29 \\
(-1.58)\end{array}$ & $\begin{array}{l}-0.33 \\
(-1.74)\end{array}$ & $\begin{array}{l}-0.31 \\
(-1.44)\end{array}$ \\
\hline Demographic Variables $^{1}$ & No & No & Yes & Yes & Yes \\
\hline Municipio Dummies & No & No & No & No & Yes \\
\hline Department Dummies & No & No & No & Yes & No \\
\hline$F$-test on Agricultural Shocks ${ }^{2}$ & $\begin{array}{c}8.32 \\
p=0.016\end{array}$ & $\begin{array}{c}8.29 \\
p=0.016\end{array}$ & $\begin{array}{c}9.55 \\
p=0.008\end{array}$ & $\begin{array}{c}8.46 \\
p=0.014\end{array}$ & $\begin{array}{c}8.00 \\
p=0.018\end{array}$ \\
\hline$F$-test on All Shocks ${ }^{2}$ & $\begin{array}{c}12.18 \\
p=0.007\end{array}$ & $\begin{array}{c}9.52 \\
p=0.023\end{array}$ & $\begin{array}{c}12.25 \\
p=0.007\end{array}$ & $\begin{array}{c}10.02 \\
p=0.018\end{array}$ & $\begin{array}{c}10.24 \\
p=0.017\end{array}$ \\
\hline Pseudo $R^{2}$ & 0.0078 & 0.0072 & 0.0137 & 0.0177 & 0.0599 \\
\hline Households & 1265 & 1265 & 1265 & 1265 & 1265 \\
\hline \multicolumn{6}{|c|}{$\begin{array}{l}{ }^{*} \text { This table contains estimates from an ordered logit model where } \\
\text { the dependent variable is migration. } \\
{ }^{* *} \text { All standard errors allow for clustering within municipios. } \\
{ }^{* * *} t \text {-statistics reported in parentheses. } \\
{ }^{1} \text { The demographic controls that were used are indicators for the } \\
\text { number of household members at home within certain age and gender } \\
\text { brackets. Details are in Section } 2.3 \text {. } \\
{ }^{2} p \text {-values are reported below each } F \text {-statistic. }\end{array}$} \\
\hline
\end{tabular}


Table 8: Marginal Impact of Shocks Northward Migration $^{1}$ Southward Migration ${ }^{2}$

\begin{tabular}{lcc}
\hline \hline & Agriculture Shocks & \\
\hline \hline Actual Distribution $^{3}$ & 0.2650 & 0.0914 \\
Absence of Shocks $^{4}$ & 0.2007 & 0.1262 \\
\% Change Between Rows 1 and 2 & $24.26 \%$ & $38.07 \%$ \\
\hline \hline & Earthquakes $^{4}$ & \\
\hline \hline Actual Distribution $^{3}$ & 0.2328 & 0.1073 \\
One SD Increase $^{5}$ & 0.1464 & 0.1682 \\
\% Change Between Rows 1 and 2 & $37.11 \%$ & $56.76 \%$
\end{tabular}

These are fitted probabilities calculated using estimates of equation (1).

Further detail concerning the calculations can be found in the appendix.

${ }^{1}$ Northward migration corresponds to the probability of $\Delta M_{h, t}>0$.

${ }^{2}$ Southward migration corresponds to the probability of $\Delta M_{h, t}<0$.

${ }^{3}$ These probabilities were calculated using the actual distribution of shocks.

${ }^{4}$ These calculations only use the fitted probabilities from 2001.

${ }^{5}$ These probabilities were calculated assuming that there were no agricultural shocks.

${ }^{6}$ This corresponds to a one standard deviation increase in the level (not the log) of damage. 
Table 9: Response of Household Remittances to Adverse Shocks

\begin{tabular}{|c|c|c|c|c|c|}
\hline & (1) & $(2)$ & (3) & (4) & (5) \\
\hline \multirow{2}{*}{ Harvest Loss } & 0.39 & 0.16 & 0.05 & 0.30 & 0.09 \\
\hline & $(1.66)$ & $(0.71)$ & $(0.18)$ & $(1.44)$ & $(0.44)$ \\
\hline \multirow{2}{*}{ Livestock Loss } & 0.61 & 0.43 & 0.40 & 0.56 & 0.40 \\
\hline & $(2.33)$ & $(1.76)$ & $(1.48)$ & $(2.30)$ & $(1.79)$ \\
\hline \multirow[t]{2}{*}{ Earthquake Damage } & -0.11 & -0.06 & -0.04 & -0.10 & -0.06 \\
\hline & $(-3.31)$ & $(-1.77)$ & $(-1.17)$ & $(-3.25)$ & $(-2.05)$ \\
\hline 2001 Dummy & $\begin{array}{c}0.82 \\
(379)\end{array}$ & $\begin{array}{c}0.62 \\
(202)\end{array}$ & 0.58 & $\begin{array}{c}0.71 \\
(345)\end{array}$ & 0.56 \\
\hline \multirow{3}{*}{$\begin{array}{l}\text { Demographic Variables }{ }^{1} \\
\text { Municipio Dummies } \\
\text { Department Dummies }\end{array}$} & No & Yes & Yes & No & Yes \\
\hline & No & No & Yes & No & No \\
\hline & No & Yes & No & No & Yes \\
\hline$F$-test on Agricultural Shocks ${ }^{2}$ & $\begin{array}{c}4.09 \\
p=0.018\end{array}$ & $\begin{array}{c}1.93 \\
p=0.149\end{array}$ & $\begin{array}{c}1.11 \\
p=0.332\end{array}$ & $\begin{array}{c}3.63 \\
p=0.029\end{array}$ & $\begin{array}{c}1.78 \\
p=0.172\end{array}$ \\
\hline$F$-test on All Shocks ${ }^{2}$ & $\begin{array}{c}6.73 \\
p=0.000\end{array}$ & $\begin{array}{c}2.33 \\
p=0.076\end{array}$ & $\begin{array}{c}1.20 \\
p=0.311\end{array}$ & $\begin{array}{c}6.22 \\
p=0.001\end{array}$ & $\begin{array}{c}2.49 \\
p=0.062\end{array}$ \\
\hline$R^{2}$ & 0.0210 & 0.1457 & 0.3442 & 0.0194 & 0.1319 \\
\hline Households & 1385 & 1265 & 1265 & 1385 & 1265 \\
\hline Dependent Variable & & Remittances & & Remittance & er Migrant \\
\hline
\end{tabular}

${ }^{*}$ This table contains results from OLS regressions where the dependent variable is remittances.

${ }^{* *}$ All standard errors allow for clustering within municipios.

${ }^{* * *} t$-statistics reported in parentheses.

${ }^{1}$ The demographic controls that were used are indicators for the number of household members at home within certain age and gender brackets.

Details are given in section 2.3 .

${ }^{2} p$-values are reported below each $F$-statistic. 
Table 10: Baseline Household Characteristics in 1997 and Shocks

\begin{tabular}{|c|c|c|c|}
\hline & Harvest Loss & Livestock Loss & Earthquake Damage \\
\hline Migrants in 1997 & $\begin{array}{c}0.009 \\
(0.80)\end{array}$ & $\begin{array}{l}0.013 \\
(1.16)\end{array}$ & $\begin{array}{l}-0.161 \\
(-2.14)\end{array}$ \\
\hline HH Size in 1997 & $\begin{array}{l}0.007 \\
(1.54)\end{array}$ & $\begin{array}{l}0.003 \\
(0.94)\end{array}$ & $\begin{array}{l}-0.004 \\
(-0.15)\end{array}$ \\
\hline Land in 1997 & $\begin{array}{l}0.000 \\
(0.12)\end{array}$ & $\begin{array}{l}-0.001 \\
(-0.30)\end{array}$ & $\begin{array}{l}-0.029 \\
(-2.71)\end{array}$ \\
\hline Head's Education in 1997 & $\begin{array}{l}-0.003 \\
(-0.93)\end{array}$ & $\begin{array}{l}-0.006 \\
(-1.99)\end{array}$ & $\begin{array}{l}0.027 \\
(1.05)\end{array}$ \\
\hline Department Dummies & Yes & Yes & Yes \\
\hline Households & 1166 & 1166 & 1166 \\
\hline
\end{tabular}




\begin{tabular}{|c|c|c|c|c|}
\hline & $\begin{array}{l}\text { le 11: Counte } \\
(1)\end{array}$ & $\begin{array}{c}\text { ctuals Shocks } \\
(2)\end{array}$ & $(3)$ & $(4)$ \\
\hline Harvest Loss & $\begin{array}{c}0.31 \\
(1.89)\end{array}$ & $\begin{array}{c}-0.23 \\
(-1.33)\end{array}$ & $\begin{array}{c}-0.15 \\
(-0.63)\end{array}$ & $\begin{array}{c}-0.25 \\
(-1.10)\end{array}$ \\
\hline Livestock Loss & $\begin{array}{c}0.36 \\
(1.84)\end{array}$ & $\begin{array}{c}-0.00 \\
(-0.02)\end{array}$ & $\begin{array}{c}0.11 \\
(0.45)\end{array}$ & $\begin{array}{c}0.06 \\
(0.27)\end{array}$ \\
\hline Earthquake Damage & $\begin{array}{l}-0.05 \\
(-2.15)\end{array}$ & $\begin{array}{c}0.00 \\
(0.02)\end{array}$ & $\begin{array}{c}0.00 \\
(0.02)\end{array}$ & $\begin{array}{c}0.00 \\
(0.05)\end{array}$ \\
\hline 2001 Dummy & $\begin{array}{c}-0.28 \\
(-1.55)\end{array}$ & $\begin{array}{c}-0.40 \\
(-2.05)\end{array}$ & $\begin{array}{c}-0.23 \\
(-0.87)\end{array}$ & $\begin{array}{c}-0.26 \\
(-1.06)\end{array}$ \\
\hline$F$-test on Agricultural Shocks ${ }^{1}$ & $\begin{array}{c}8.32 \\
p=0.016\end{array}$ & $\begin{array}{c}1.78 \\
p=0.411\end{array}$ & $\begin{array}{c}0.23 \\
p=0.796\end{array}$ & $\begin{array}{c}0.61 \\
p=0.546\end{array}$ \\
\hline$F$-test on All Shocks ${ }^{1}$ & $\begin{array}{c}12.18 \\
p=0.007\end{array}$ & $\begin{array}{c}1.79 \\
p=0.616\end{array}$ & $\begin{array}{c}0.15 \\
p=0.923\end{array}$ & $\begin{array}{c}0.41 \\
p=0.746\end{array}$ \\
\hline Counter-factual Shocks? ${ }^{2}$ & No & Yes & Yes & Yes \\
\hline Households & 1265 & 1244 & 1244 & 1244 \\
\hline Dependent Variable & Migrant-Diffs & Migrant-Diffs & Remit.-Diffs & Remit./Mig.-Diffs \\
\hline Estimation Method & Ordered Logit & Ordered Logit & OLS & OLS \\
\hline
\end{tabular}

*All standard errors allow for clustering within municipios.

${ }^{* *} t$-statistics in parentheses.

${ }^{1} p$-values are reported below each $F$-statistic.

${ }^{2}$ Counter-factual shocks are the 2001 shocks merged into the 1999 data and the 1999 shocks merged into the 2001 data. 
Table 12: Migratory Responses to Adverse Shocks - Southward Migration

\begin{tabular}{|c|c|c|c|c|c|}
\hline & (1) & (2) & (3) & (4) & (5) \\
\hline Harvest Loss & $\begin{array}{l}0.16 \\
(0.65)\end{array}$ & $\begin{array}{c}0.08 \\
(0.31)\end{array}$ & $\begin{array}{c}0.23 \\
(0.90)\end{array}$ & $\begin{array}{c}0.17 \\
(0.67)\end{array}$ & $\begin{array}{c}0.25 \\
(1.03)\end{array}$ \\
\hline Livestock Loss & $\begin{array}{c}0.26 \\
(0.84)\end{array}$ & $\begin{array}{c}0.20 \\
(0.61)\end{array}$ & $\begin{array}{c}0.28 \\
(0.89)\end{array}$ & $\begin{array}{c}0.27 \\
(0.84)\end{array}$ & $\begin{array}{c}0.26 \\
(0.81)\end{array}$ \\
\hline Earthquake Damage & $\begin{array}{c}0.01 \\
(0.45)\end{array}$ & $\begin{array}{l}-0.05 \\
(-1.96)\end{array}$ & $\begin{array}{c}0.01 \\
(0.37)\end{array}$ & $\begin{array}{c}0.01 \\
(0.21)\end{array}$ & $\begin{array}{l}-0.00 \\
(-0.11)\end{array}$ \\
\hline Earthquake Damage * Land & - & - & - & $\begin{array}{l}0.002 \\
(0.34)\end{array}$ & $\begin{array}{l}0.005 \\
(1.10)\end{array}$ \\
\hline Land & - & - & $\begin{array}{l}-0.07 \\
(-2.85)\end{array}$ & $\begin{array}{l}-0.02 \\
(-1.70)\end{array}$ & $\begin{array}{l}-0.09 \\
(-2.76)\end{array}$ \\
\hline Land $^{2}$ & - & - & $\begin{array}{l}0.001 \\
(1.78)\end{array}$ & - & $\begin{array}{c}0.002 \\
(1.63)\end{array}$ \\
\hline $\begin{array}{l}2001 \text { Dummy } \\
\text { Demographic Variables }{ }^{1}\end{array}$ & $\begin{array}{c}-0.78 \\
(-3.58) \\
\text { No }\end{array}$ & No & $\begin{array}{c}-0.76 \\
(-3.43) \\
\end{array}$ & $\begin{array}{c}-0.76 \\
(-3.38)\end{array}$ & $\begin{array}{c}-0.72 \\
(-3.11) \\
\text { Yes }\end{array}$ \\
\hline$F$-test on Agricultural Shocks ${ }^{2}$ & $\begin{array}{c}1.08 \\
p=0.583\end{array}$ & $\begin{array}{c}0.45 \\
p=0.797\end{array}$ & $\begin{array}{c}1.49 \\
p=0.476\end{array}$ & $\begin{array}{c}1.11 \\
p=0.574\end{array}$ & $\begin{array}{c}1.56 \\
p=0.459\end{array}$ \\
\hline$F$-test on All Shocks ${ }^{2}$ & $\begin{array}{c}1.41 \\
p=0.704\end{array}$ & $\begin{array}{c}3.94 \\
p=0.268\end{array}$ & $\begin{array}{c}1.72 \\
p=0.632\end{array}$ & $\begin{array}{c}1.20 \\
p=0.754\end{array}$ & $\begin{array}{c}1.56 \\
p=0.667\end{array}$ \\
\hline $\begin{array}{l}\text { Pseudo } R^{2} \\
\text { Households }\end{array}$ & $\begin{array}{l}0.0124 \\
1265\end{array}$ & $\begin{array}{c}0.0033 \\
1265\end{array}$ & $\begin{array}{c}0.0173 \\
1265\end{array}$ & $\begin{array}{c}0.0148 \\
1265\end{array}$ & $\begin{array}{c}0.0336 \\
1265\end{array}$ \\
\hline
\end{tabular}

${ }^{*}$ This table contains estimates from an ordered logit model where the dependent variable is southward migration.

${ }^{* *}$ All standard errors allow for clustering within municipios.

${ }^{* * *} t$-statistics reported in parentheses.

${ }^{* * * *}$ These results use land 1 as the land variable.

${ }^{1}$ The demographic controls that were used are indicators for the number of household members at home within certain age and gender brackets. Details are in section 2.3 .

${ }^{2} p$-values are reported below each $F$-statistic. 
Table 13: Migratory Responses to Adverse Shocks - Northward Migration

\begin{tabular}{|c|c|c|c|c|c|}
\hline & (1) & $(2)$ & (3) & $(4)$ & (5) \\
\hline Harvest Loss & $\begin{array}{c}0.38 \\
(1.96)\end{array}$ & $\begin{array}{c}0.35 \\
(1.78)\end{array}$ & $\begin{array}{c}0.40 \\
(2.02)\end{array}$ & $\begin{array}{c}0.44 \\
(2.09)\end{array}$ & $\begin{array}{c}0.46 \\
(2.15)\end{array}$ \\
\hline Livestock Loss & $\begin{array}{c}0.38 \\
(1.83)\end{array}$ & $\begin{array}{c}0.37 \\
(1.78)\end{array}$ & $\begin{array}{c}0.43 \\
(2.10)\end{array}$ & $\begin{array}{c}0.31 \\
(1.27)\end{array}$ & $\begin{array}{c}0.32 \\
(1.32)\end{array}$ \\
\hline Earthquake Damage & $\begin{array}{c}-0.09 \\
(-3.24)\end{array}$ & $\begin{array}{c}-0.08 \\
(-3.17)\end{array}$ & $\begin{array}{c}-0.07 \\
(-2.54)\end{array}$ & $\begin{array}{l}-0.07 \\
(-2.26)\end{array}$ & $\begin{array}{c}-0.07 \\
(-2.32)\end{array}$ \\
\hline Earthquake Damage * Land & - & - & $\begin{array}{l}-0.002 \\
(-0.45)\end{array}$ & $\begin{array}{l}-0.004 \\
(-0.76)\end{array}$ & $\begin{array}{l}-0.004 \\
(-0.72)\end{array}$ \\
\hline Land & - & $\begin{array}{c}0.05 \\
(2.33)\end{array}$ & $\begin{array}{l}0.03 \\
(2.97)\end{array}$ & $\begin{array}{l}0.03 \\
(2.74)\end{array}$ & $\begin{array}{l}0.03 \\
(2.71)\end{array}$ \\
\hline Land $^{2}$ & - & $\begin{array}{l}-0.001 \\
(-1.20)\end{array}$ & - & - & - \\
\hline 2001 Dummy & $\begin{array}{l}-0.00 \\
(-0.02)\end{array}$ & $\begin{array}{l}-0.04 \\
(-0.21)\end{array}$ & $\begin{array}{l}-0.09 \\
(-0.47)\end{array}$ & $\begin{array}{c}-0.09 \\
(-0.44)\end{array}$ & $\begin{array}{c}-0.09 \\
(-0.41)\end{array}$ \\
\hline Migrants in 1997 & - & - & - & $\begin{array}{c}0.22 \\
(2.65)\end{array}$ & $\begin{array}{c}0.22 \\
(2.66)\end{array}$ \\
\hline Head's Education in 1997 & - & - & - & - & $\begin{array}{c}0.03 \\
(1.23)\end{array}$ \\
\hline Demographic Variables $^{1}$ & No & No & Yes & Yes & Yes \\
\hline$F$-test on Agricultural Shocks ${ }^{2}$ & $\begin{array}{c}8.90 \\
p=0.011\end{array}$ & $\begin{array}{c}8.01 \\
p=0.018\end{array}$ & $\begin{array}{c}11.67 \\
p=0.003\end{array}$ & $\begin{array}{c}8.59 \\
p=0.014\end{array}$ & $\begin{array}{c}9.11 \\
p=0.011\end{array}$ \\
\hline$F$-test on All Shocks ${ }^{2}$ & $\begin{array}{c}16.88 \\
p=0.001\end{array}$ & $\begin{array}{c}15.70 \\
p=0.001\end{array}$ & $\begin{array}{c}15.83 \\
p=0.001\end{array}$ & $\begin{array}{c}12.44 \\
p=0.006\end{array}$ & $\begin{array}{c}12.84 \\
p=0.005\end{array}$ \\
\hline Pseudo $R^{2}$ & 0.0115 & 0.0156 & 0.0286 & 0.0340 & 0.0350 \\
\hline Households & 1265 & 1265 & 1265 & 1165 & 1165 \\
\hline
\end{tabular}

${ }^{*}$ This table contains estimates from an ordered logit model where the dependent variable is northward migration.

${ }^{* *}$ All standard errors allow for clustering within municipios.

${ }^{* * *} t$-statistics reported in parentheses.

${ }^{* * * *}$ These results use land 1 as the land variable.

${ }^{1}$ The demographic controls that were used are indicators for the number of household members at home within certain age and gender brackets. Details are in section 2.3.

${ }^{2} p$-values are reported below each $F$-statistic. 
Table 14: Southward and Northward Migration Results with Alternative Land Measures Southward Migration

\begin{tabular}{|c|c|c|c|c|c|c|}
\hline & \multicolumn{2}{|c|}{$\overline{\text { Land } 1}$} & \multicolumn{2}{|c|}{ Land 2} & \multicolumn{2}{|c|}{ Land 3} \\
\hline $\begin{array}{l}\text { Earthquake } \\
\text { Damage } * \text { Land }\end{array}$ & - & $\begin{array}{l}0.002 \\
(0.34)\end{array}$ & - & $\begin{array}{l}-0.000 \\
(-0.09)\end{array}$ & - & $\begin{array}{l}0.002 \\
(0.39)\end{array}$ \\
\hline Land & $\begin{array}{c}-0.07 \\
(-2.85)\end{array}$ & $\begin{array}{c}-0.02 \\
(-1.70)\end{array}$ & $\begin{array}{c}-0.08 \\
(-2.77)\end{array}$ & $\begin{array}{c}-0.02 \\
(-1.38)\end{array}$ & $\begin{array}{c}-0.07 \\
(-2.97)\end{array}$ & $\begin{array}{c}-0.03 \\
(-1.78)\end{array}$ \\
\hline Land $^{2}$ & $\begin{array}{l}0.001 \\
(1.78) \\
\end{array}$ & - & $\begin{array}{l}0.001 \\
(1.45) \\
\end{array}$ & - & $\begin{array}{l}0.001 \\
(1.74) \\
\end{array}$ & - \\
\hline \multicolumn{7}{|c|}{ Northward Migration } \\
\hline $\begin{array}{l}\text { Earthquake } \\
\text { Damage }{ }^{*} \text { Land }\end{array}$ & - & $\begin{array}{l}-0.001 \\
(-0.22)\end{array}$ & - & $\begin{array}{l}-0.001 \\
(-0.31)\end{array}$ & - & $\begin{array}{l}-0.001 \\
(-0.18)\end{array}$ \\
\hline Land & $\begin{array}{c}0.05 \\
(2.33)\end{array}$ & $\begin{array}{c}0.03 \\
(2.38)\end{array}$ & $\begin{array}{c}0.06 \\
(3.15)\end{array}$ & $\begin{array}{c}0.03 \\
(1.98)\end{array}$ & $\begin{array}{c}0.06 \\
(2.48)\end{array}$ & $\begin{array}{c}0.03 \\
(2.45)\end{array}$ \\
\hline Land $^{2}$ & $\begin{array}{l}-0.001 \\
(-1.20)\end{array}$ & - & $\begin{array}{l}-0.001 \\
(-1.84)\end{array}$ & & $\begin{array}{l}-0.001 \\
(-1.28)\end{array}$ & - \\
\hline
\end{tabular}

*This table contains regressions like those in Tables 12 and 13 except that alternative land measures have been used. Each regression includes the listed variables as well as the shock variables and the year dummy.

**All standard errors allow for clustering within municipios.

${ }^{* * *} t$-statistics are in parentheses. 
Figure 1: Earthquake Damage Densities by Department
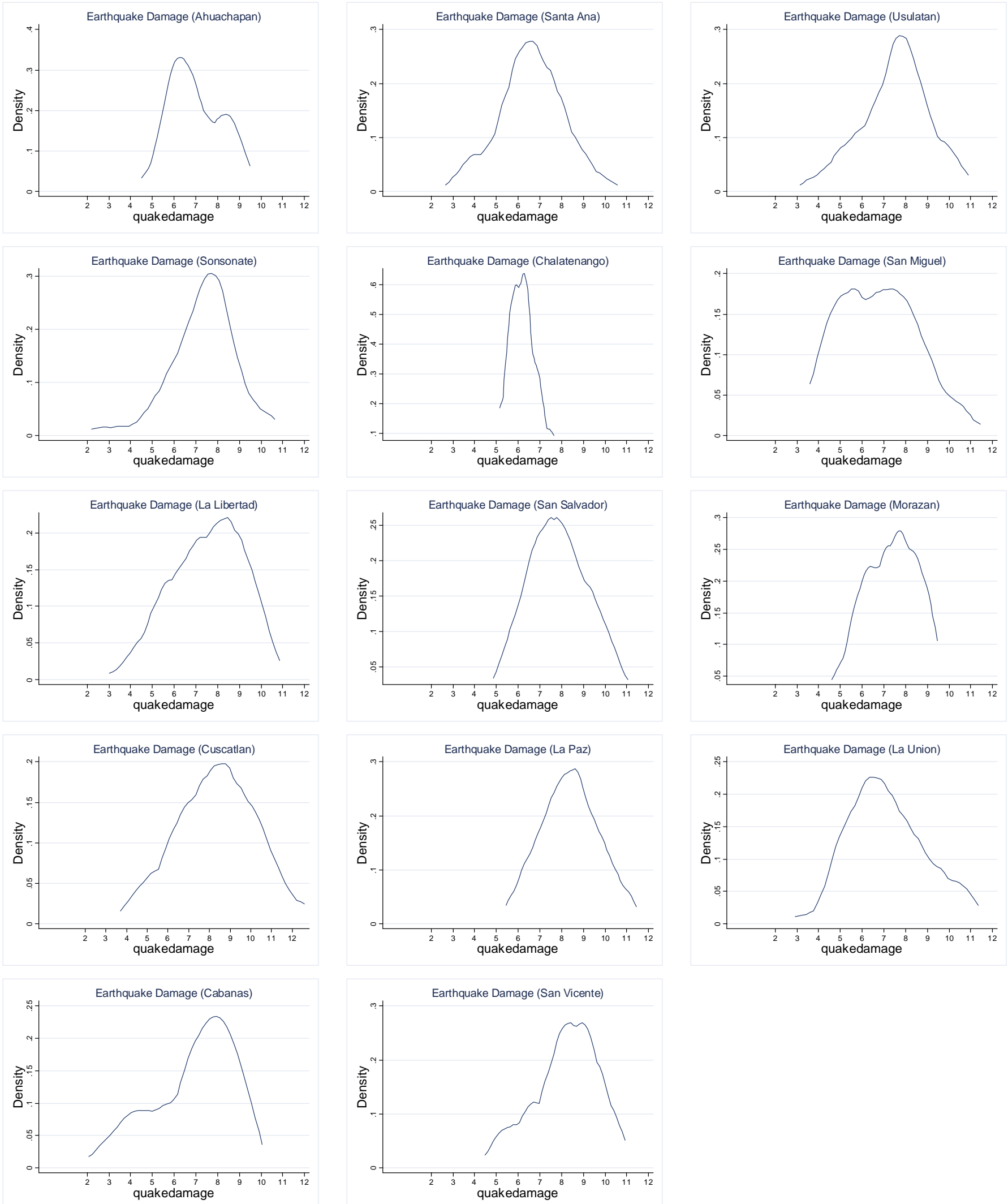